\title{
AÇÕES EMPRESARIAIS E FORMAÇÃO PROFISSIONAL Serviço Nacional de Aprendizagem Industrial
}

\author{
Carmen Sylvia Vidigal Moraes \\ Professora da Faculdade de Educação da Universidade de São Paulo
}

\begin{abstract}
Resumo: Examinam-se as ações institucionais de ajuste do "modelo de educação profissional" do Sistema Nacional de Aprendizagem Industrial - Senai às mudanças em curso na economia e no sistema educacional brasileiro. As reformulações na política interna da agência estão definidas no seu Plano Estratégico para o qüinqüênio 1996-2001. Embora a análise priorize as modalidades de cursos ofertados aos trabalhadores do ramo metalúrgico, a abrangência das informações levantadas permite abordar o panorama geral da formação profissional realizada na instituição e apontar problemas comuns às políticas formativas.

Palavras-chave: ensino-aprendizagem; formação docente; educação e trabalho.
\end{abstract}

$\mathrm{N}$ as últimas décadas, em um contexto de crise econômica e globalização dos mercados, de mudanças nos padrões tecnológicos e organizacionais, a educação readquire importância central nas políticas governamentais e no discurso do empresariado.

Não só no Brasil ou em outros países periféricos, mas também nos países centrais do capitalismo, a educação aparece relacionada a um conjunto de preocupações de ordem particularmente econômica e é convertida em resposta estratégica às necessidades impostas pelas aceleradas mudanças tecnológicas, pela nova ordem de competição internacional.

A emergência dos "novos modelos produtivos" suscitou acirrado debate sobre os novos requisitos de qualificação para o trabalho, provocou reformulações no conceito tradicional de formação profissional e tem levado a tentativas de redefinição das atribuições sociais da educação escolar, ao estabelecimento de "relações orgânicas entre escola e empresa" (Tanguy, 1986).

No caso dos países latino-americanos, em processo de ajustamentos econômicos ao novo padrão de acumulação, um "novo" paradigma educacional, construído a partir das orientações de organismos internacionais, como o Banco Internacional para Reconstrução e Desenvolvimento (Bird), o Banco Interamericano de Desenvolvimento (BID) e a Cepal/Unesco, conforma as agendas dos governos da região, definindo metas e objetivos aos sistemas de edu- cação nacionais. Esse novo paradigma, alinhado ao quadro mais geral das reformas de Estado e ao modelo de desenvolvimento em curso, propõe como objetivo prioritário da educação nacional o investimento na melhoria da qualidade da mão-de-obra para o mercado, ao mesmo tempo que concebe a formação profissional como elemento constitutivo de uma política de emprego.

No Brasil, no que diz respeito às modalidades de educação para o trabalho não vinculadas aos sistemas públicos de ensino, consolidou-se historicamente o monopólio do ensino profissional pelo empresariado. O Serviço Nacional de Aprendizagem Industrial - Senai, instituição criada há 58 anos, constitui, hoje, ao lado do treinamento nas empresas, a principal opção nacional para trabalhadores jovens e adultos empregados. ${ }^{1}$

$\mathrm{O}$ artigo examina as ações institucionais de ajuste do "modelo de educação profissional" do Senai às mudanças em curso na economia e no sistema educacional brasileiro. As reformulações na política interna da agência estão definidas no seu Plano Estratégico para o próximo qüinqüênio (1996 a 2001).

Embora a análise privilegie as modalidades de cursos ofertados aos trabalhadores do ramo metalúrgico, a abrangência das informações levantadas permite abordar o panorama geral da formação realizada na instituição e, resguardadas as especificidades das áreas de profissionalização, apontar problemas comuns às políticas formativas. 


\section{SENAI: ESTRUTURA E ORGANIZAÇÃO}

Projeto longamente acalentado por importante facção da elite empresarial paulista, o Senai é criado no governo de Getúlio Vargas, através do Decreto-Lei de 20 de janeiro de 1942, 30 anos após a instalação das escolas profissionais oficiais, federais e estaduais. Suas atividades se iniciam em São Paulo, no mesmo ano, e tem como diretor o engenheiro e professor da Escola Politécnica, Roberto Mange. ${ }^{2}$ Em 1946, o Decreto-Lei no 9.576 determinou que o Conselho Nacional do Senai fixasse o número de aprendizes entre $5 \%$ e $15 \%$ dos trabalhadores das empresas associadas, conforme as necessidades da indústria.

O Senai é, desde sua fundação, financiado com recursos públicos: contribuição parafiscal de $1 \%$ sobre o total da folha de pagamento mensal das empresas, vinculadas por lei à instituição. Empresas com mais de 500 empregados recolhem um adicional de $0,2 \%$ sobre a folha de pagamentos diretamente ao Departamento Nacional do Senai. $^{3}$

As empresas contribuintes do Senai totalizam, em todo o Brasil, 359.446 estabelecimentos. Só no Estado de São Paulo, estão localizadas 91.953 empresas contribuintes que empregam 2.591.880 trabalhadores, aproximadamente 50\% do total da força de trabalho empregada no setor industrial do país. ${ }^{4}$

Embora mantido com recursos públicos, a gestão do Senai é de natureza privada. Apenas as federações e confederações empresariais têm ingerência efetiva na definição de suas políticas de formação e em sua gestão administrativa.

Ele organiza-se em dois blocos fundamentais: de um lado, os órgãos normativos da instituição, compostos pelo Conselho Nacional e pelos conselhos regionais; de outro lado, os órgãos de administração, representados pelo Departamento Nacional e 27 departamentos regionais. É função do Departamento Nacional coordenar a execução da política e das normas definidas pelo Conselho Nacional, organizando/orientando o conjunto dos departamentos regionais que, por sua vez, são os responsáveis diretos pela implementação dos programas de educação profissional.

Considerado a maior rede de ensino privado do país, em termos de formação, especialização e aperfeiçoamento da mão-de-obra, atua em diversas áreas, entre as quais destacam-se: alimentos, artes gráficas, cerâmica, confecção, construção civil, eletroeletrônica, informática, instrumentação, mecânica, mobiliário, petroquímica, plásticos, refrigeração, soldagem, têxtil e outras. É importante assinalar que a maior proporção de atendimentos se realiza no setor metalmecânico, seguido do eletroeletrônico.

Apresenta duas vertentes de "atendimento às empresas e à comunidade": a Educação Profissional e a Prestação de Serviços Técnicos e Tecnológicos direcionada também para empresas e comunidade. As diferentes modalidades de "educação profissional" - cursos regulares e livres, técnicos e de especialização - são ofertadas em suas próprias unidades, nas empresas e nos sindicatos e organizadas de acordo "com o domínio de conhecimentos, habilidades e atitudes compatíveis com um determinado posto de trabalho qualificado" (Senai, 1997a).

Para a efetivação de seus serviços, o Senai dispõe de uma vasta rede escolar que inclui centros de tecnologia, centros de educação profissional, centros de treinamento, unidades de treinamento operacional, agências de treinamento, agências de educação profissional, unidades móveis e unidades difusoras de informações, totalizando 934 unidades operacionais (627 administradas com recursos próprios e 307 em parceria com empresas), distribuídas pelas diferentes regiões do país (Senai, 1997a; 1997b) . $^{5}$

Para atender às diversas demandas educacionais, o Senai, além do corpo administrativo e gerencial constituído de 5.765 pessoas, possui 6.275 professores e 2.311 técnicos, dos quais aproximadamente $60 \%$ estão na região Sudeste. ${ }^{6}$

Apesar de, recentemente, ter iniciado reformas para implantação de uma administração mais participativa, trata-se de uma organização de gestão altamente centralizada nos processos decisórios. As orientações pedagógicas são deliberadas no plano da Administração Central, ouvidas as escolas e com base em pesquisas realizadas sistematicamente pelo Centro Internacional para a Educação, Trabalho e Transferência de Tecnologia (Ciet) e alguns departamentos regionais (São Paulo e Rio de Janeiro, por exemplo), incluindo-se os Cenatecs, que disponibilizam informações para todo o sistema Senai. É importante observar que o Senai dispõe do único observatório de situações de emprego e formação profissional do país, ainda que dirigido para o estudo e atendimento das demandas pontuais de suas empresas contribuintes.

\section{O SENAI E AS MUDANÇAS}

As alterações nos perfis dos trabalhadores provocadas pelas mudanças nos processos produtivos e na organização do trabalho e, em decorrência, as novas e crescentes demandas pela reformulação dos programas e currículos 
da formação profissional induzem o Senai a realizar uma série de reformulações internas com o objetivo de resguardar "a sintonia com o mercado de trabalho".

É importante ressaltar as tensões provenientes das críticas realizadas pelos organismos internacionais - como o Banco Internacional de Reconstrução e Desenvolvimento (Bird), o Banco Interamericano de Desenvolvimento (BID), Comissão Econômica para a América Latina e o Caribe (Cepal) e seus consultores brasileiros sobre o "envelhecimento" e desatualização da instituição ante as novas "condições do mercado". Cláudio Moura Castro, um dos principais representantes do "pensamento único" na educação brasileira, ex-consultor do Bird e, hoje, conselheiro-chefe do BID, avalia em documento recente sobre as estratégias do Banco na área da capacitação a necessidade urgente e inadiável da reforma do Senai, no Brasil, e de suas congêneres latino-americanas: "Há 20 anos eram o orgulho da América Latina; um sistema de instituições ricas e bem administradas, em agudo contraste com a pobreza e mediocridade das escolas de ensino acadêmico. Entretanto, a partir das crises econômicas da década de 70 começaram a experimentar dificuldades para colocar seus egressos e foram lentas em adaptar-se às novas circunstâncias. Além do mais envelheceram, não reagiram com rapidez e, em alguns casos, foram infiltradas pela politização e sindicalização de seus empregados. Desmoralizaram-se cada vez mais e passaram a ser percebidas mais como um problema do que uma solução. A terceirização e outras mudanças econômicas provocaram erosão nas suas fontes financeiras. Não há soluções fáceis para as instituições que enfrentam os problemas mais graves, pois conservam força política e resistem a toda tentativa de modificá-las ou fechá-las. Sua reforma constitui um grande desafio para o BID” (Moura Castro, 1999).

No mesmo documento, indicando a "experiência considerável do Banco em formação profissional e técnica", esse consultor salienta o apoio da agência financeira aos "sistemas tradicionais" de formação profissional do tipo Senai/Sena/INA como uma linha de projetos prioritários, ao lado do apoio às escolas técnicas, consideradas como "uma área tradicional que cresceu em importância com a ênfase recente colocada no ensino secundário pelos países membros". Nessa medida, o financiamento da reforma dessas instituições é considerado prioridade estratégica "número um" para a consecução do "objetivo comum" de ajustamento da formação profissional às necessidades do mercado.

Assim, para o conselheiro do BID, é preciso delimitar as táticas e os espaços de atuação do Banco. Os organis- mos multilaterais "podem apoiar a mudança mas não promovê-la", o que "requer um diálogo íntimo e constante por parte dos interessados". É essencial "estabelecer confiança entre o Banco e seus sócios" e, em especial, "prestar mais atenção no papel dos Ministérios do Trabalho, que na maioria dos países exercem função reguladora dos institutos de formação". Mas, uma vez construída a legitimidade da reforma, os empréstimos estarão precedidos da realização, pelas instituições tradicionais de formação profissional, de "uma análise institucional cuidadosa" e do "estudo da factibilidade política de diferentes cenários para efetuar mudanças. Não menos importante é a análise do mercado de capacitação...".

João Batista de Oliveira, outro conhecido consultor do Bird, ${ }^{8}$ ainda em 1995, no seminário internacional organizado pela Fiemg, afirma a impossibilidade de o governo ser capaz de resolver "todos os problemas da nação", até mesmo "problemas tão agudos como o da educação básica". Na área da educação e da formação profissional, "que se tornaram imbricadas", cabia à sociedade organizada e, de modo particular, ao setor empresarial, um papel fundamental: "não se trata apenas de gerenciar recursos do governo, trata-se de participar coletivamente na definição de políticas, no custeio e também na gestão desses sistemas" (Oliveira, 1995).

Evidencia-se claramente uma reconceituação da formação profissional e a redefinição das atribuições da educação escolar no seu conjunto. E, nesse processo de ajustamento do ensino a necessidades do mercado do trabalho, propõe-se a aproximação entre a empresa e a escola pelo envolvimento ampliado do empresariado tanto na definição dos rumos e do financiamento da formação profissional, no acompanhamento das escolas do Senai, como nas demais questões sobre educação básica - fundamental e média. Considera-se vital "oferecer subsídos ao governo federal para a reformulação da legislação de aprendizagem e financiamento da formação profissional" (Oliveira, 1995). ${ }^{9}$

Como é possível verificar, as propostas dos organismos internacionais que orientam tendencialmente as reformas educacionais dos países latino-americanos e, em particular, as do nosso país incidem sobre o conjunto do sistema educacional, integrando e definindo as atribuições das instituições de diferentes tipos, níveis e modalidades de ensino, das redes públicas e privadas. Ou seja, mais especificamente, só podemos apreender o significado das mudanças nas políticas públicas se analisarmos sua relação com as mudanças desenvolvidas no Senai. 
Nessa perspectiva, o referido consultor aprecia positivamente as diretrizes propostas pelo Ministério da Educação e Cultura para a "reconversão das escolas técnicas", as quais seriam regulamentadas pelo Decreto no 2.208/97 que introduziu na rede pública as principais inovações já adotadas pelo Senai no seu sistema de aprendizagem. Ou seja, seguindo a direção apontada por essa agência, as escolas técnicas iriam, por um lado, separar o ensino acadêmico do ensino técnico-profissional e, de outro, introduzir o ensino modularizado: "repensar seu ensino profissional a partir de categorias diferentes, tendo como parâmetros o perfil ocupacional e a demanda dos mercados de trabalho - e não os currículos montados a partir de disciplinas acadêmicas ou da disponibilidade de professores especializados". Ao mesmo tempo, essas escolas, excessivamente dispendiosas, deveriam "estabelecer parcerias com o setor privado e ouvi-lo na determinação de seus rumos". Enfim, para "ajustar o currículo ao mercado", é preciso "ajustar o corpo docente ao currículo" e "ajustar as escolas ao mercado" - e, nesse aspecto, tal como no Senai, "as escolas deverão passar a ter conselhos de administração formados pelos empresários da região", para que possa "orientar seus rumos de maneira mais ajustada à realidade", isto é, às demandas das empresas locais (Oliveira, 1995). ${ }^{10}$

A desvalorização do público passa pela sua redefinição conceitual, pela sua distinção do que é estatal. No entanto, na "nova" acepção, originária das teorias liberais conservadoras que elegem o mercado como instância estrita de regulação da vida social, o público reduz-se basicamente aos interesses privados. Tal posição, na verdade, opõe-se àquela outra, defendida por setores sociais comprometidos com a democratização da sociedade, que, no processo de novo significado do público, critica justamente a privatização da esfera pública e reivindica a sua divulgação, isto é, a existência de transparência nas políticas públicas, a participação dos coletivos sociais na sua definição, a gestão pública dos fundos públicos, de modo a empreender uma forma de regulação democrática, negociada, pela qual os interesses econômicos e os direitos sociais são arbitrados em seu próprio princípio público (Paoli, 1999).

Conforme o conselheiro-chefe do BID, em uma economia moderna, a soma das iniciativas privadas e dispersas - incluindo ONGs, cursos por correspondência, TV e vídeos, "com alcances ilimitados ao ensino" - poderia ser várias vezes mais importante que a capacitação pública oficial. Na sua concepção, é preciso distinguir entre o financiamento público da formação profissional e sua ad- ministração pelo Estado. Se o primeiro é inevitável, o segundo pode, para garantir a eficiência da gestão, ser evitado. Ao contrário dos EUA, onde grandes empresas como a Boeing, Caterpillar e os principais fabricantes de automóveis estão passando cada vez mais suas atividades de formação a instituições públicas, "não há dúvida de que na maioria dos países latino-americanos a formação profissional deve continuar sendo administrada privadamente". Nesse sentido, segundo o autor, "o BID favorece diversas pautas organizativas para a 'capilaridade' dos sistemas", a extensão do alcance da capacitação - ONGs, instituições com fins lucrativos, etc. Para isso, sugere "a liberação de licenças ou franquias (franchising), formal ou metaforicamente", como uma das possibilidades de "combinar a perícia técnica das instituições tradicionais com uma descentralização radical da formação e uma redução de custos" (Moura Castro, 1999).

Em resumo, na situação atual, "onde há maior exigência de qualidade e quantidade", "a marca Senai, Senac ou das escolas técnicas" não é suficiente para sinalizar a qualidade da formação profissional, tornando-se então necessário o desenvolvimento de mecanismos externos de calibração, como os sistemas de certificação profissional. Ou seja, multiplicam-se as habilidades requeridas, flexibilizam-se os currículos, programas e formas de treinamento. Daí a necessidade de "padronizar os mecanismos de avaliação, aferição e de controle de qualidade". No conjunto, "era necessário fazer uma revolução nas políticas, na filosofia e no financiamento e nas organizações responsáveis pela formação profissional e ensino técnico" (Oliveira, 1995).

A adoção de pressupostos dos organismos multilaterais na ordenação das políticas educacionais do país é, pois, bastante clara. As preocupações com a identidade do ensino médio e a otimização da relação custo-benefício direcionaram o processo de reorientação desse nível do ensino básico que culminou na proposta de sua flexibilização. Referenciando-se no Senai, o MEC promoveu a "desescolarização" do ensino técnico e determinou, nas instituições públicas de ensino profissional, a oferta de cursos modulares de qualificação, de curta duração e completamente dissociados da educação básica, destinados à população adulta de baixa escolaridade. Abre-se para as escolas técnicas a perspectiva de, como o "Sistema S", transformar suas atividades educativas em serviços a serem vendidos especialmente às empresas. Em resumo, a reforma não só promove o desmonte do sistema público de ensino técnico como também estimula sua privatização. ${ }^{11}$ 
No caso específico do Senai, "instituição que provê praticamente todos os cursos de aprendizagem no país", Oliveira (1995) enfatiza, entre as estratégias propostas: "ajustar melhor os cursos ao mercado de trabalho, maior flexibilidade institucional, ajustar melhor a dosagem de conteúdos teórico-práticos e desenvolver, no ensino prático, habilidades básicas de que carece a grande maioria da força de trabalho formal e informal". Para isso, tornase fundamental "uma profunda revisão no conceito e utilização das séries metódicas", além da "capacidade de produzir cursos de alta qualidade associada a uma distribuição de ensino cada vez mais próxima da clientela". O consultor sugere, então, "uma cadeia de franchising de produtos padronizados de alta qualidade sobretudo para os cursos mais simples", o que implica "importantes mudanças na forma de conceber a função e estrutura de órgãos como o Senai, Senac e Sesi”.

Nessas condições, seguindo as sugestões dos bancos, o Senai realizou, no mesmo ano de 1995, uma ampla sondagem para verificar, junto aos funcionários, as perspectivas das mudanças a serem realizadas na instituição. Foram ouvidas, também, opiniões de "seus interlocutores externos" - empresários, representantes do governo, representantes das organizações de trabalhadores, da universidade, ex-alunos e agências financiadoras da formação profissional. Segundo a instituição, os resultados da sondagem subsidiaram a elaboração de um plano de reformas que começou a ser implementado em 1996. ${ }^{12}$

\section{A REFORMULAÇÃO DO MODELO DE FORMAÇÃO PROFISSIONAL DO SENAI}

A discussão interna realizada pelo Senai sobre o(s) modelo(s) de formação profissional aponta, como já se observou, a necessidade de ampliação dos seus campos de atuação. Ante a tendência do setor industrial em terceirizar suas atividades, propõe-se que "os setores nãoindustriais sejam atendidos quando estiverem relacionados com a produção industrial". Nesses casos, "seriam efetuadas parcerias e seriam cobrados os serviços prestados pelo Senai" (Senai, 1997a).

A prioridade é atribuída às empresas contribuintes, mas o atendimento às demais é visto como "fonte de receitas alternativas". Nessa mesma perspectiva, inclui-se o atendimento às micros e pequenas empresas.

Embora ainda perdure a polêmica sobre a origem dos recursos que mantêm o Senai, documentos elaborados pelo seu Departamento Nacional e por várias regionais já re- conhecem explicitamente que os recursos são públicos, provenientes de contribuição parafiscal da mesma natureza que o Salário Educação - outro dos recursos públicos voltados para o ensino (fundamental). A grande discussão desloca-se, agora, para a questão da mudança na contribuição compulsória, "mudança interpretada como ameaça à sobrevivência do Sistema", e para o desenvolvimento de outras formas de financiamento da instituição.

Apesar das incertezas que cercam o debate do tema, o Senai considera que, entre os empresários, prevalece a idéia da permanência do atual sistema de contribuição compulsória, baseado na folha de pagamentos. A autosustentação, total ou parcial, já é considerada como meta da instituição e algumas medidas são indicadas para sua implementação: cobrança pelos cursos, assistência técnica, consultoria, serviços em laboratórios, emissão de certificados de qualidade, aluguel de instalações, entre outras (Senai, 1997a).

Quanto à educação para o trabalho há, no plano discursivo, consenso sobre o Senai das prioridade à educação profissional e a rede pública/privada, inclusive o Sesi, privilegiar a educação geral. Entretanto, o Senai deve ter um papel ativo na definição das políticas educacionais, tanto nacionais (com ênfase na atuação junto aos Ministérios da Educação, do Trabalho e da Ciência e Tecnologia) quanto estaduais (onde as relações com as Secretarias de Educação devem ser estreitadas) (Senai, 1996).

Recomenda-se, com o objetivo de "estreitamento das relações entre os sistemas de educação básica e de educação profissional", a realização de parcerias que dêem prioridade ao Sesi e entidades públicas e privadas. Propõese, também, a participação do Senai nos Conselhos Estaduais de Educação e nos Conselhos Universitários. Ao mesmo tempo, considera-se a necessidade da criação de comissões temáticas sobre educação na Federação das Indústrias.

A reestruturação do Modelo de Formação do Senai prioridade estratégica apontada por todos os departamentos regionais em função das "transformações socioeconômicas e educacionais do país" - torna-se diretriz do Departamento Nacional e integra projetos de âmbito nacional e regional. Tendo em vista a multiplicidade de demandas, considerou-se fundamental, para dinamizar e dar flexibilidade ao atendimento da instituição, "a realização periódica de estudos e pesquisas para identificar e interpretar as demandas por educação profissional, assistência técnica e tecnológica e para análise de tendências de mercado, conferindo, dessa forma, maior rigor e precisão 
na identificação da demanda". Os canais considerados privilegiados foram: sistema de acompanhamento de exalunos junto ao mercado; pesquisa baseada em dados secundários; estudo de mercado com foco nas empresas e auto-emprego. Nessa direção, os estudos desenvolvidos pelo Senai-SP, Senai-RJ e Ciet, pela importância e abrangência qualitativa dos resultados obtidos, são particularmente relevantes para a compreensão da natureza da reformulação empreendida nos processos formativos da instituição (Moraes e Ferretti, 1999).

No âmbito dos aspectos metodológicos, em sintonia com as recomendações dos consultores do Bird e BID, as indicações foram no sentido de "adaptar a educação profissional às demandas do mercado", para: "reestruturar o conteúdo programático; reformular a metodologia; requalificar docentes e técnicos; atualizar material didático e equipamentos". Considerou-se fundamental "deixar de agir com visão de tarefa e atuar/agir com visão de processo", desenvolvendo currículos modularizados que tornem viáveis "entradas e saídas entre escola/mercado, itinerários individualizados e atendimento a toda uma família ocupacional". Enfatiza-se a necessidade de mudança "naquela que seria a mais importante metodologia da instituição - as Séries Metódicas Ocupacionais (SMOs)". Conforme os relatórios do Senai, "atualizadas e revistas, as séries metódicas ocupacionais constituir-se-iam em recurso de grande significação para a formação profissional, notadamente na formação de trabalhadores dotados de habilidades de manipulação de máquinas e ferramentas. Atualizadas, portanto, com base em novos estudos ocupacionais, seriam reeditadas mediante a utilização de novos recursos didáticos" (Senai, 1996).

Com o objetivo de "elevar a competência técnica dos seus recursos humanos e a capacidade de assimilar e difundir novas tecnologias", o Senai tem ampliado as parcerias no plano internacional. Essas parcerias, estabelecidas por cooperação entre governos, envolvem, entre outros, países como Alemanha, Canadá, França, Espanha, Israel, Japão, Portugal, Suécia e Suíça (Senai-SP, 1997b). $\mathrm{Na}$ França, as relações com a Association Nationale pour la Formation Professionnelle des Adultes (AFPA), do Ministério do Trabalho, Emprego e Formação Profissional, o principal instituto de formação daquele país, propiciaram o aprendizado da organização de cursos modularizados para a construção de itinerários formativos. Outro desses programas, destinado prioritariamente aos docentes de formação especial, consiste na disseminação do Modelo Petra de formação profissional. ${ }^{13}$ Trata-se, se- gundo o Relatório do Senai, de um projeto estratégico do Departamento Nacional, de âmbito regional (Sudeste), que tem como objetivo "aperfeiçoar o modelo de formação profissional da instituição, proporcionando aos alunos, além da qualificação técnica, o domínio de determinadas qualificações-chave necessárias para os desafios do mundo do trabalho" (Senai, 1997b).

\section{O SISTEMA DE EDUCAÇÃO PROFISSIONAL DO SENAI-SP}

A partir dos resultados da pesquisa/diagnóstico sobre o mercado de trabalho em São Paulo, o Senai-SP elaborou projeto de organização do Sistema de Formação Profissional que pretende, basicamente, articular as ações de formação já realizadas numa nova dinâmica e numa nova estrutura curricular.

A pesquisa, realizada com o objetivo de complementar as informações levantadas pela Pesquisa Industrial de Amostragem (Piam),${ }^{14}$ forneceu subsídios para a construção dos novos perfis profissionais e a revisão dos cursos e currículos na área metalmecânica, de eletroeletrônica e de metalurgia e exigiu aprofundamento e revisão do referencial teórico. ${ }^{15}$ Em consonância com o processo de reformulação conceitual orientado pela Secretaria Nacional de Formação (Sefor), do Ministério do Trabalho, redefiniu-se o conceito tradicional de formação profissio-nal, revisouse noções como ocupação, qualificação e competência, ao mesmo tempo que se introduziu o uso de novas expressões para designar as novas relações de trabalho em curso, tais como empregabilidade e trabalhabilidade.

O Senai entende que um modelo de formação profissional adequado a uma realidade em constante mutação é aquele que responde às exclusividades regionais e à necessidade de os indivíduos poderem construir sua formação no decorrer do tempo, "agregando novos conteúdos que ampliem suas competências e que facilitem sua inserção e permanência no mercado de trabalho" (Senai, 1997b:3).

Dessa maneira, conforme documentos analisados e entrevistas realizadas, a reformulação do modelo Senai-SP de formação profissional objetiva propiciar e aumentar as condições de empregabilidade dos trabalhadores por meio de educação continuada. As novas condições do mercado de trabalho deveriam impor uma mudança de foco do emprego para a empregabilidade. A instituição entende empregabilidade como "a capacidade de um profissional continuar apto a permanecer no mundo do trabalho, mesmo com as mudanças contínuas que o têm afetado. Esse con- 
ceito está muito ligado à idéia de que "a competência é o capital do trabalhador", significando que só quem é capaz de aprender continuamente terá, no futuro, trabalho e remuneração (Senai, 1997b:3).

Baseado nos pressupostos teóricos fornecidos pela Teoria do Capital Humano, uma exclusividade das Teorias (marginalistas) do Desenvolvimento, em voga no final dos anos 60 e 70 e, hoje, retomada com particular ênfase nas análises econômicas da educação, o conceito de empregabilidade remete ao trabalhador a responsabilidade pela sua situação de emprego ou desemprego. Nessa abordagem, a educação/formação profissional é vista como o instrumento de construção da empregabilidade, da conformação das competências - capital humano valorizável no mercado.

De acordo com o Senai, empregabilidade "não é um conceito fechado". Ao contrário, vem passando por reformulações constantes: "Para alguns, o que se impõe é ir além da empregabilidade e garantir a trabalhabilidade aos indivíduos, isto é, torná-los aptos ao desempenho de atividades com ou sem vínculo empregatício" (Senai, 1997b). Em outras palavras, em um mercado onde a ênfase é dada à redução dos custos do capital e se flexibilizam as relações de trabalho, a orientação é a de se construir um modelo aberto, não apenas direcionado para o emprego.

Nessa mesma direção, as mudanças no mercado tornam indispensável a reformulação do conceito de "ocupação", base do planejamento educacional do Senai. Se, tradicionalmente, ele é definido como "um conjunto de postos de trabalho agrupados por semelhanças de suas tarefas principais", atualmente, a partir das novas demandas do mercado por um trabalhador "versátil", "com livre trânsito tanto intra como interempresas", não mais formado "para exercer qualificações fixas", o novo conceito de ocupação passa a ser entendido como: "um conjunto de competências comuns mobilizadas no desempenho de atividades para a elaboração de um produto ou serviço" (Defune, 1997).

Tal compreensão informa a metodologia da pesquisa. $\mathrm{Na}$ análise da estrutura ocupacional do mercado de trabalho em que o Senai atua, utilizaram-se os dados reorganizados de maneira a constituir famílias ocupacionais, "conceito mais abrangente que o de posto de trabalho". O profissional procurado hoje "tem de ter competências diversas para atuar em diversos postos de trabalho e é condição que ele conheça, se possível, todo o processo produtivo....". ${ }^{16}$

A conformação das famílias ocupacionais pressupõe, por sua vez, clara definição do que seja competência. A noção de competência não é originária do campo da educação, mas dos negócios (Hirata, 1994, 1997;
Ferretti, 1999; Deluiz, 1996; Moraes et alii, 1998). Originária do discurso empresarial e, portanto, marcada política e ideologicamente por sua origem, substitui num contexto de crise do modelo taylorista/fordista o conceito de qualificação (um dos conceitos-chave da sociologia do trabalho francesa). Há alguns anos, nos países onde se desenvolveu o Estado do Bem-Estar como a França, Inglaterra e Alemanha, por exemplo falava-se de qualificação. E essa noção se relacionava àquela de negociação social, de convenção coletiva de trabalho. Agora, com os novos modelos de organização industrial e a introdução da automatização de base microeletrônica, fala-se de competência e se considera o indivíduo no trabalho. Nesse quadro, as empresas passam a usar e adaptar as aquisições individuais de formação, sobretudo escolar, em função de suas exigências. A aprendizagem é orientada para a ação, e a avaliação das competências baseia-se nos resultados observáveis, verificáveis. A tendência é lhe atribuir o sentido de performance individual, de desempenho verificável em situações e trabalhos específicos, o que indica um deslocamento importante em direção à individualização crescente de apreciação dos assalariados.

Para apreciar a extensão dessa problemática, seria oportuno citar o Livro Branco da Comissão Européia que apresenta uma alternativa ao modelo atual, ainda vigente na grande parte dos países da União Européia, distinguindo um sistema voltado para o passado e outro voltado para o futuro. Ele opõe, assim:

- qualificação concebida como um conjunto de competências fortemente articuladas entre elas, ligadas a identidades profissionais fortes e a uma lógica de ramos e de níveis formativos, à qualificação como combinatória individual de competências construídas graças às formações modulares;

- a autonomia profissional, ligada a um certo tipo de organização do trabalho, à autonomia como faculdade de adaptação permanente por iniciativa pessoal;

- uma transmissão essencialmente estruturada de conhecimentos à aquisição de saberes em situação.

Em resumo, o livro opõe um modelo do passado, baseado na dimensão coletiva da competência, ao modelo do futuro, apoiado na sua dimensão individual. De acordo com certos autores (Merle, 1997; Joubier, 1997), essa oposição sistemática parece excessiva e coloca problemas para o meio sindical: como integrar as competências dos trabalhadores de uma empresa em uma lógica coletiva? Como combinar o aumento desejável da autonomia dos indivíduos e a ne- 
cessidade crescente de referências obrigatoriamente coletivas? Em outras palavras, como as competências são construídas e avaliadas? Quais são os critérios de julgamento? Como e por quem as competências são validadas, certificadas? As empresas não correm o risco de julgar os indivíduos em função de seus objetivos próprios?

O Senai-SP não ignora a polêmica conceitual. Mas entende que há convergências nessas posições: "a noção de competência no mundo do trabalho se situa 'entre os saberes e as habilidades concretas; a competência é inseparável da ação, mas também exige conhecimento'. Ou seja, competência é saber fazer e também saber por que fazer". Considera importante, na elaboração de currículos e programas educacionais, diferenciar competências do trabalho de competências pedagógicas ou, como preferem alguns, competências reais de típicas: "Estudos, pesquisas e observações da realidade das empresas trarão informações sobre as competências reais ou do trabalho. As competências típicas ou pedagógicas são a tradução que os especialistas fazem delas de modo a estruturar se ensino e aprendizagem" (Senai, 1997c) .

Nesse ponto, o Senai indica que assimilou o modelo escolar da competência. Desde os anos 80 , uma série de iniciativas nos países centrais e, que chegam agora ao Brasil, dão forma a uma pedagogia da competência. Ou, como bem descreve Tanguy (1994), a passagem de um ensino centrado sobre saberes disciplinares a um ensino definido para produzir competências verificáveis em situações e trabalhos específicos. Assinala o momento das grandes avaliações nacionais, como o que estamos vivendo, todas com a mesma preocupação de proceder a partir de critérios objetivos e de medir a capacidade dos alunos em efetuar uma operação ou um trabalho determinado em uma situação dada. No caso do ensino técnico, o diploma se apresenta como uma longa lista de competências a adquirir, quer este certificado seja preparado em uma escola técnica ou resultado de uma aprendizagem na empresa.

Finalmente, afirma que nessa revisão de conceito, o de flexibilidade não está claro tanto na literatura especializada como na fábrica. Se, para alguns, trabalhadores flexíveis e polivalentes seriam os multifuncionais, "capazes de executar alternadamente diferentes tarefas/operações", para outros, "como Salm e Fogaça, a polivalência refere-se ao maior envolvimento direto do trabalhador em decisões que antes não lhe competiam" (Salm e Fogaça apud Senai, 1997b). ${ }^{17}$

Essa (re)definição conceitual e a leitura que ela permite dos resultados da pesquisa sobre o mercado de tra- balho, em São Paulo, informa o novo modelo de formação profissional. ${ }^{18}$ De acordo com o Relatório do Senai, os dados indicam, em termos tendenciais, que a configuração tradicional do mercado de trabalho paulista não se alterou substancialmente e que o processo em curso de reestruturação produtiva apresenta-se de forma bastante parcial e heterogênea, estando longe de corresponder a uma transformação radical e sem contradições, rumo ao paradigma "pós-fordista". Com base nessas indicações, o Senai-SP concluiu, por um lado, que todas as modalidades de formação devem ter seu lugar no âmbito da instituição: se as inovações não acontecem igual e simultaneamente em todos os segmentos do sistema produtivo e tampouco em todas as regiões, "modalidades mais antigas de formação profissional podem estar superadas em certos segmentos, mas permanecem atuais em outros". Por outro lado, sobre o conteúdo dos programas, traduz como expectativa das empresas "que o foco da formação deixe de concentrar-se em uma ocupação específica e propicie uma formação mais geral, trabalhando atitudes, relações humanas, capacidade de análise, modelos de organização do trabalho, ampliando os conhecimentos de informática e diluindo as fronteiras entre as áreas ocupacionais". De acordo com o Senai-SP, "o cliente não está preocupado com que o profissional seja portador de um acúmulo de informações técnicas específicas, mas sim que ele conheça o básico do processo". Segundo a instituição, são três os aspectos ressaltados pelos entrevistados para aperfeiçoar a formação dos alunos: ampliação da formação básica; ampliação e atualização do conhecimento técnico; desenvolvimento de atitudes pessoais.

Para o Senai-SP, a elevação do nível dos cursos de formação profissional deve provocar a elevação formal do requisito de escolaridade para sua realização; os pré-requisitos de ingresso definem o perfil de quem entra nos cursos. Baseiam-se em exigências educacionais que têm como pressupostos os conhecimentos mínimos necessários para o ensino da teoria e das práticas profissionalizantes. O processo de seleção é visto como indispensável para que a agência garanta a oferta de formação compatível com o padrão de qualidade que o mercado de trabalho exige. Entretanto, segundo o Senai, a medida não provoca maior elitização dos cursos, uma vez que a diversificação de programas formativos atenua a seletividade. Outros grupos da população (os de baixa escolaridade e os excluídos do mercado formal) são atendidos em programas menos caros e de curta duração, desenvolvidos em parceria com empresas e a comunidade. A flexibilidade organi- 
zacional que rege esses programas permite, a seu ver, compatibilizá-los com o nível educacional da demanda e, assim, os objetivos e conteúdos curriculares são ajustados ao nível socioeconômico e cultural dos participantes. Afirma que a ação do Senai nessa faixa é considerável, pois entende que os cursos/treinamentos industriais ministrados nas empresas e na comunidade teriam essas características e constituiriam $87 \%$ das matrículas em programas formativos em 1996 (Senai, 1997b).

Com base nas informações levantadas, estruturou-se o sistema de educação profissional do Senai-SP, cuja dinâmica está baseada em três aspectos considerados inovadores e que visam em conjunto uma economia da formação profissional: o aproveitamento de estudos e de experiências anteriores; a certificação de competências; a modularização das programações (Senai, 1997d). ${ }^{19}$

Afirmando atribuir prioridade à formação de pessoas que ainda não ingressaram no mercado de trabalho, privilegiando, portanto, a formação de jovens, define a educação continuada como o eixo de sustentação do modelo, que oferece, também, a possibilidade de reconversão e requalificação a trabalhadores adultos, além das oportunidades de atualização, aperfeiçoamento e especialização profissional.

Segundo o Senai, o modelo proposto, estruturado em currículos modulares, pretende oferecer programações que, num crescendo de formação, elevem o nível de competência dos trabalhadores, desde um patamar em que ainda não dominaram habilidades básicas consideradas pré-requisitos para a aprendizagem de competências profissionais (Pré-formação), passando por uma formação considerada geral e introdutória para o desenvolvimento profissional posterior e permanente (Formação Básica) e atingindo patamar de sua formação em nível técnico (Formação do Técnico). A proposta importante da formação básica é o oferecimento, ao aluno, de módulos destinados não apenas à formação em uma determinada profissão, mas que enriqueçam essa formação com saberes, saber fazer e saber ser, de outras profissões a ela relacionadas, as chamadas famílias ocupacionais. $\mathrm{Na}$ verdade, a idéia central, de acordo com a instituição, é permitir percursos de formação que visem a polivalência profissional.

Os concluintes da etapa de formação básica e de mais um módulo, pelo menos, do nível de qualificação receberão certificados que poderão valer como créditos nas etapas subsequientes. Àqueles que possuírem a condição de empregado-aprendiz, nos termos da CLT, e que comprovarem a conclusão do ensino fundamental, será concedi- do o Certificado de Aprendizagem Industrial. Após a realização do período de prática profissional nas empresas o aluno receberá a Carta de Ofício. A próxima etapa para alunos que completaram a formação básica pode ser a escolha de uma qualificação ou a do percurso da formação de técnico, no nível médio (ou $2^{\circ}$ grau).

Na formação do técnico, assim como na formação básica, estão previstas oportunidades de formação em determinada profissão e em profissões correlatas, "sempre na busca da polivalência profissional".

O modelo prevê os chamados subsistemas de suporte à educação profissional. No Sistema de Educação a Distância, o candidato que demonstrar falta de algum tipo de conhecimento no exame de comprovação de competências poderá tentar adquiri-lo através da realização de estudos individualizados com material instrucional, sob monitoria de uma escola da rede. O aluno poderá, por exemplo, seguir o curso profissionalizante do Telecurso 2000, desenvolvendo a prática profissional em oficinas e laboratórios de escolas da rede. No Sistema de Certificação, responsável por fornecer atestados de conclusão de cada módulo cursado, o aluno poderá ir colecionando os certificados para compor seu percurso profissional no ritmo que lhe for mais adequado.

Não é necessário enfatizar que a implementação do Sistema de Educação Profissional pela Regional São Paulo tem implicações relevantes para todo o Sistema Senai, uma vez que, se tiver êxito, deverá referenciar a montagem do processo de formação em outras regionais, senão em todas elas. No que se refere especificamente ao método de certificação ocupacional, definido pelo Senai como o reconhecimento formal da qualificação profissional do trabalhador, destinado a validá-la independentemente da forma como foi adquirida, a experiência de São Paulo poderá contribuir para ampliar a ação do Senai no atendimento às demandas de mão-de-obra com programas de reconhecimento e validação de competências de trabalhadores não só empregados, mas subempregados e desempregados, conforme seus objetivos.

Nos últimos 20 anos, a OIT e o Cinterfor realizaram inúmeros estudos sobre Certificação Ocupacional para delinear uma política para a América Latina sobre a matéria. Com a difusão de normas de qualidade como a série ISO 9000 e a ISO 14000, a certificação passou a ser uma exigência internacional, e, como se viu, alguns países da Europa e os Estados Unidos realizam programas de educação profissional que já conduzem os egressos à certificação profis-sional, uma vez que organismos oficiais li- 
gados aos empregadores e empregados participam de todo o processo (Senai, 1995).

O modelo oficial de certificação de conformidade, utilizado hoje no Brasil, surgiu em 1973, a partir da Lei no 5.966, que criou o Sinmetro. Nesse modelo, cabe ao Inmetro conceder a marca nacional de conformidade aos produtos. No entanto, diversos órgãos da sociedade já praticavam, e ainda praticam, a atividade de certificação fora do âmbito do governo. De acordo com o Senai, apesar dos vários esforços realizados, o número de ocupações profissionais certificadas no Brasil é muito pequeno se comparado aos países do Primeiro Mundo. Para essa instituição, o Programa Brasileiro de Qualidade e Produtividade (PBQP), através do Subprograma IV - Adequação dos Serviços Tecnológicos para a Qualidade e Produtividade, o qual ela integra, propiciou a preparação de um sistema brasileiro de certificação, cujas normas dispõem sobre a conformidade de produtos, serviços, sistemas e pessoal, que considera coerente com a atualidade.

O Senai se coloca como um agente certificador cuja experiência deve ser usada na montagem do sistema nacional de certificação. Nessa direção, segundo o Departamento Nacional, a instituição vem contribuindo com o processo de Certificação Ocupacional, oferecendo apoio à Associação Brasileira de Manutenção (Abraman), à Associação Brasileira de Ensaios NãoDestrutivos (Abende), e à Fundação Brasileira de Tecnologia de Soldagem (FBTS) na certificação de pessoal nas áreas respectivas.

Hoje, o Sistema Senai tem implantado cinco Centros de Exame de Qualificação (Cequal), nas áreas de caldeiraria, mecânica, eletricidade e ensaios não-destrutivos, distribuídos nos departamentos regionais do Senai do Rio de Janeiro e Bahia. Desde 1996 estão sendo implantados mais 12 Centros de Exame de Qualificação, abrangendo também as áreas de soldagem, instrumentação e eletrônica e a participação dos departamentos regionais de Minas Gerais, Rio Grande do Sul, São Paulo e Espírito Santo.

Conforme o disposto no artigo 7ํ do Decreto 2.208/ 97, que reformulou o ensino técnico de nível médio, a certificação por competências exigirá, para sua implantação, que sejam realizados estudos de identificação do perfil e das competências necessários à atividade requerida e que sejam ouvidos os setores interessados, trabalhadores e empregadores incluídos.

Recentemente, o governo, impulsionado pelo Mercosul, iniciou o processo para elaboração de um Projeto Nacio- nal de Certificação Profissional. A Secretaria de Formação Profissional (Sefor/Mtb) realizou, com o apoio da OIT e da assessoria do Cinterfor, um seminário internacional sobre o tema que resultou na proposta de organização de um grupo tripartite, isto é, formado por representantes dos empresários, dos trabalhadores e do governo, com o objetivo de elaborar um projeto piloto. A estratégia definida "seria partir das experiências de certificação já existentes, basicamente as da Abraman, F. Odebrecht, Senac, Senai, as desenvolvidas no campo dos trabalhadores, observatórios de emprego e se poderia incluir, também, o Sine. Essas experiências iriam progressivamente sendo harmonizadas até constituírem um sistema homogêneo, mantendo as devidas diferenças e particularidades de cada setor" (Brigido, 1998).

Apesar do mérito da proposta em organizar um grupo tripartite e procurar reunir experiências provenientes dos diferentes sujeitos sociais, sabe-se que essas iniciativas são escassas na área governamental e que os trabalhadores praticamente iniciaram o debate a respeito. Além disso, é importante enfatizar que a elaboração negociada do projeto piloto de certificação não foi concretizada até agora, quase três anos após ser anunciada. Nessas circunstâncias, não é difícil deduzir que as referências para o desenvolvimento do Sistema Nacional de Certificação serão provenientes das ações empresariais e, principalmente, do "Sistema S".

Como tivemos a oportunidade de salientar, as matrizes que orientam a revisão do modelo de formação/certificação profissional realizada pelo Senai inspiram-se em experiências européias, particularmente alemãs e francesas. Atualmente, após o programa Petra, na Alemanha, e o ensino modular, na França, o modelo inglês de certificação das competências tem atraído a atenção da instituição. A parceria, estabelecida com o British International Training (BIT), intermediada pelo Conselho Britânico, tem como principal objetivo "dotar o Senai-SP de condições metodológicas e técnicas para implantar o seu sistema institucional na área de certificação profissional e ser um pólo difusor e multiplicador da concepção do modelo". Inclusive, "a instituição poderá colaborar com o Ministério da Educação tanto na implantação do Sistema Nacional de Certificação, quanto na definição da forma como esse sistema pode se articular com os países-membros do Mercosul (Argentina, Brasil, Paraguai e Uruguai)". O projeto piloto em desenvolvimento privilegiou a área de telecomunicações (Senai, 1999).

Não deixa de despertar interesse essa recente opção do Senai em se aproximar do sistema inglês de formação pro- 
fissional. Se, por um lado, sua procura e aproximação de diversas experiências, particularmente dos países europeus, baseadas em concepções teóricas e dinâmicas sociais distintas, indicam um momento de insegurança e imprecisão conceitual, por outro lado, a escolha final do modelo britânico sugere que essa busca pode estar terminada, que a instituição, mais definida teórica e politicamente, encontrou afinal os referenciais desejados. De fato, o desenho institucional de formação daquele país está, hoje, muito mais próximo, em termos de concepção, das metas empresariais e dos propósitos da agência que a francesa ou alemã, por exemplo.

A partir dos anos 80, sob o governo conservador de Margareth Thatcher, ocorreram importantes mudanças nas relações industriais acompanhadas de uma reforma radical nas instituições de formação, consideradas bastante polêmicas por sindicalistas (em particular, o sindicato geral da metalurgia Amalgamed Engineering Union (AEU), com 700 mil associados) e pesquisadores britânicos. Segundo alguns dos especialistas, "as instâncias de regulação existentes foram suprimidas e o governo parou de intervir diretamente nas políticas de formação das empresas, marcando assim a passagem de um sistema paritário a um regime neoliberal". E, "as novas instituições, criadas na escala local, extinguiram um modelo fundado sobre a 'negociação social' para dar mais peso ao patronato" (Rainbird, 1995).

Tal como no Brasil, as formas, os lugares e os conteúdos da formação permanecem variáveis e muito dependentes das características do mercado de trabalho e das condições locais da oferta de formação. Em sua maioria, os programas são definidos pelos empregadores (na escala individual ou de suas organizações). Em cada setor industrial, as normas têm sido definidas pelas instâncias de dirigentes industriais (Training Agency), em que as posições dos empregadores dominam fortemente, ainda que os professores e os sindicatos possam, quando convidados, emitir seu ponto de vista (Tanguy e Rainbird, 1995). As formas de autoridade locais, fundadas na cooperação entre instâncias administrativas, Local Educationnal Authorities (LEA), em matéria de educação e nos acordos entre empregadores/empregados sobre aprendizagem, foram substituídas por quadros regulamentares nacionais em termos de certificação, notadamente (Rainbird, 1995).

Para alguns autores, críticos do modelo, a instauração do novo sistema de qualificações profissionais visou aumentar sua transparência para os empregadores e erguer um sistema de unidades de competências que permitam aos operários progredir por etapas. Ao contrário de outros sistemas de qualificação, o processo de aprendizagem não é considerado como central e seu conteúdo não é preciso, levando-se em conta a capacidade de realizar uma tarefa conforme a norma. A experiência profissional pode ser igualmente avaliada e contribuir para validar unidades de competência, o que é designado como "validar saberes adquiridos". Em outros termos, tal como se considera na França e é proposto pelo Senai aqui no Brasil, a competência pode ser legitimada na ausência de toda ação formativa ou de escolaridade. Na Inglaterra, há ainda o agravante de não existir exames escritos e de estar delegada às hierarquias empresariais a atribuição de avaliar, além do "caráter extremamente inferior do primeiro nível de competências certificado pelo sistema National Council for Vocational Qualifications (NVCQ), sem equivalente em outros países da Europa" (Rainbird, 1995).

De acordo com Rainbird, os novos modos de representação instaurados fizeram prevalecer o ponto de vista do patronato na elaboração das normas (oficiais) de competência e essas normas "estão mais adaptadas às exigências a curto prazo que às necessidades futuras da produção". Além disso, são utilizados procedimentos da análise funcional (e behavioristas) na definição e na validação das competências, o que acentua, ainda mais, os seus limites. E, uma vez que o taylorismo repousa sobre métodos da análise funcional, a autora considera, juntamente com Fuller, que "a adoção, na empresa, de um sistema de avaliação fundado na competência vem reforçar os métodos de gerência científica muito mais que contribuir para suprimi-los em benefício de um sistema de qualificações mais elevadas" (Fuller apud Rainbird, 1995). ${ }^{20}$

Não é difícil concluir que essa incorporação de modelos não pode ignorar as especificidades da sociedade brasileira, cuja dramaticidade do alcance ou qualidade das políticas sociais, da inexistência de relações democráticas de trabalho e de negociações coletivas entre patrões e empregados nos diferentes setores econômicos e categorias de trabalhadores, produziu, no caso da educação, altos índices de analfabetismo e de baixa escolaridade, além de um sistema previdenciário incapaz, entre outras coisas, de tornar viável o seguro-desemprego tanto aos trabalhadores desempregados de mais longa duração, ${ }^{21}$ como aos jovens com problemas de colocação profissional.

Nesses termos, em primeiro lugar a implantação do sistema de certificação de competências é, na Inglaterra, parte do processo em curso de enfraquecimento dos sindicatos, de encolhimento das instâncias de negociação social, e de 
crescimento do poder de decisão das representações empresariais, particularmente das grandes corporações. Em nosso país, onde os trabalhadores sempre foram impedidos pelas empresas e pelo Estado de participar da definição de políticas de formação profissional, no momento em que - apesar das coibições neoliberais - se abrem perspectivas de formalização de alguns espaços de participação social nessa área, o fato de o Senai referenciar-se no modelo inglês provoca certo estranhamento pois, certamente, introduz alguns riscos para o recém-iniciado processo de construção do novo sistema de certificação, como o do alijamento dos trabalhadores e o da manutenção da predominância do poder patronal nas decisões. Nesse caso, o sistema não estará voltado para as necessidades do conjunto da economia em matéria de qualificação, mas centrado sobre demandas pontuais do mercado ou, mais exatamente, das grandes empresas, reforçando o processo de segmentação do mercado de trabalho que só permite o acesso à formação para certos trabalhadores assalariados. E, mesmo para esses, a possibilidade e qualidade da formação, capazes de tornar viável a construção de sua polivalência/competência, permanecem no âmbito do poder de decisão da gestão empresarial e da sua disposição em transformar, de fato, os processos produtivos em organizações qualificantes. Por sua vez, a organização dos conteúdos curriculares em módulos certificáveis, além dos aspectos críticos já mencionados, pode originar um mercado "lucrativo" de certificações pela iniciativa privada, de consequiências previsíveis.

Em segundo lugar, se, por um lado, no Brasil, a validação de conhecimentos adquiridos pela experiência pode ser vista como uma via possível de democratização da educação e da formação, uma vez que possibilitaria aos trabalhadores a progressão de um nível para outro, além de instaurar certificados reconhecidos nas diferentes esferas do mercado de trabalho, por outro, na ausência das representações de trabalhadores, pode ser a via mais rápida para legitimar a ausência de educação escolar básica às milhares de pessoas que a ela não tiveram acesso na idade adequada. Entre elas, os jovens da faixa etária que não encontram vagas nas escolas e não têm acesso a cursos profissionalizantes, ou os menores de 16 anos que, apesar das disposições legais impeditivas, são obrigados a trabalhar para sobreviver e, por isso, se afastam da escola. Tais riscos são consideráveis tendo em vista a educação de jovens e adultos, pois a nova Lei de Diretrizes e Bases (LDB) não discrimina as esferas responsáveis por esses programas, e tanto o ensino supletivo como a alfabetização de adultos constitu- em modalidades não-contempladas pela Lei do Fundo de Manutenção e Desenvolvimento do Ensino e Valorização do Magistério (Fundef). Em síntese, a desvalorização do certificado escolar e sua substituição pelo sistema nacional de validação de competências, definido a partir de interesses empresariais, pode significar, ao mesmo tempo, a desistência do poder público em promover a efetivação do direito à educação ao conjunto da população, a introdução de maior seletividade e elitização no acesso à formação, e, conseqüentemente, a criação de uma nova hierarquia ocupacional acompanhada do aumento da exclusão social.

\section{CONSIDERAÇÕES FINAIS SOBRE AS MUDANÇAS NO MODELO DE FORMAÇÃO}

Dados recentes fornecidos em documentos publicados pelo Senai-SP permitem visualizar, pelo movimento do montante de matrículas e conclusões nos cursos, e pelo atendimento do número de alunos/hora, o processo de implantação da reforma no período entre 1996 e 1998.

Reafirmando a tendência geral apontada nos últimos anos em todas as regionais, o item "Aprendizagem Industrial" vem perdendo peso no conjunto da carga horária do Senai-SP: $-25,23 \%$ de matrículas entre 1998/95 (-17,3\% entre 1998/97); $-2,6 \%$ de conclusões no mesmo período (-5,0\% entre 1998/97). O número de alunos/hora caiu de 25.209.751 para 19.725.664, o que equivale a $-21,13 \%$ de alunos/hora nesses quatro anos (entre 1998/ $97,-16,8 \%)$.

No caso do "Ensino Técnico", reestruturado para atender às determinações da nova LDB, é interessante observar que embora as matrículas e as conclusões venham crescendo desde 1995, se analisarmos o ano de 1998 em relação ao anterior, 1997, elas decaíram $2,4 \%$ e 3,9\%, respectivamente. Em termos de alunos/hora, há um decréscimo de 4,2\% em relação a 1997.

As matrículas e conclusões nos cursos de formação intensiva, aperfeiçoamento e especialização, que já vinham caindo desde 1995, sofrem redução expressiva entre 1998/ 1997: de -67,2\% e -69,5\% (de 19.958 para 6.547 matrículas e 16.596 para 5.070 conclusões).

Tais reduções refletem as orientações do Senai em fortalecer suas novas modalidades de cursos - "programas flexíveis" e "qualificação profissional" que, na expressão da instituição, significam a diversificação da oferta da educação profissional, com a multiplicação de possibilidades de soluções personalizadas para os itinerários de formação nas áreas profissionais. Como é possível 
TABELA 1

Matrículas, Conclusões, Evasões, Matrículas Residuais e Alunos/Hora no Senai-SP, segundo Modalidades Estado de São Paulo - 1996

\begin{tabular}{|c|c|c|c|c|c|}
\hline Modalidades & Matrículas & Conclusões & Evasões & Matrículas Residuais & Alunos/Hora \\
\hline TOTAL (1) & 1.253 .502 & 1.191 .742 & 41.486 & 20.274 & $77.044 .288,7$ \\
\hline Ação Direta (2) & 551.695 & 497.785 & 34.086 & 19.824 & $64.760 .794,7$ \\
\hline \multicolumn{6}{|l|}{ Aprendizagem Industrial - Fase Escolar } \\
\hline Modalidade 1 (3) & 80 & 79 & 1 & - & $66.462,0$ \\
\hline Modalidade 2 (4) & 21.155 & 7.777 & 879 & 12.499 & $25.209 .751,0$ \\
\hline Qualificação Profissional & 19.288 & 16.477 & 2.811 & - & $3.875 .716,0$ \\
\hline \multicolumn{6}{|l|}{ Curso Técnico (HP) } \\
\hline Fase Escolar (2) & 3.083 & 846 & 129 & 2.108 & $3.385 .944,0$ \\
\hline Estágio & 1.959 & 410 & 22 & 1.527 & $1.907 .901,0$ \\
\hline \multicolumn{6}{|l|}{ Curso Técnico Especial (CQP - IV) } \\
\hline Fase Escolar & 2.246 & 1.126 & 239 & 881 & $1.527 .600,0$ \\
\hline Estágio & 1.128 & 553 & - & 575 & $1.015 .200,0$ \\
\hline \multicolumn{6}{|l|}{ Curso Técnico Modularizado - Formação de } \\
\hline \multicolumn{6}{|l|}{ Auxiliares Técnicos } \\
\hline Fase Escolar & 3.295 & 2.407 & 354 & 534 & $1.459 .065,0$ \\
\hline Especialização & 7.680 & 6.589 & 618 & 473 & $2.303 .274,5$ \\
\hline Aperfeiçoamento & 2.351 & 1.195 & 287 & 869 & $519.788,0$ \\
\hline Treinamento Industrial & 373.990 & 354.108 & 19.524 & 358 & $12.161 .416,8$ \\
\hline Iniciação Profissional & 114.662 & 105.454 & 9.208 & - & $11.239 .831,4$ \\
\hline Outras & 778 & 764 & 14 & - & $88.845,0$ \\
\hline Ação Indireta & 701.807 & 693.957 & 7.400 & 450 & $12.283 .494,0$ \\
\hline \multicolumn{6}{|l|}{ Aprendizagem Industrial - Fase Escolar } \\
\hline Modalidade 2 (4) & 559 & 231 & 18 & 310 & $700.197,5$ \\
\hline \multicolumn{6}{|l|}{ Curso Técnico Especial (CQP - IV) } \\
\hline Fase Escolar & 196 & 68 & 34 & 94 & $111.720,0$ \\
\hline Estágio & 195 & 149 & - & 46 & $154.340,0$ \\
\hline Treinamentos - Acordos & 344.959 & 342.998 & 1.961 & - & $4.003 .874,0$ \\
\hline Treinamentos - Termos de Cooperação & 355.898 & 350.511 & 5.387 & - & $7.313 .362,5$ \\
\hline
\end{tabular}

Fonte: Senai, 1997b.

(1) Não inclui estágios para pessoal de empresas no país e no exterior (78 matrículas, 78 conclusões e $4.712,0$ alunos/hora). Não inclui, também, 3.148 certificados expedidos em exames supletivos (1.758 - disciplinas de 10 grau, 962 - disciplinas do $2^{\circ}$ grau e 428 - profissionalizantes) - Telecurso 2000.

(2) No caso do regime semestral, inclui até $06^{0}$ semestre da fase escolar. 0 70 semestre acha-se somado com o estágio.

(3) Inclui estudos de educação geral considerados equivalentes aos realizados em uma das quatro últimas séries do ensino de 10 grau.

(4) Inclui apenas disciplinas profissionalizantes.

observar na Tabela 5, em 1998, os "programas flexíveis" incorporaram 52.179 matrículas e 46.435 conclusões, o que significa uma taxa de evasão de $11 \%$. Com relação à duração desses cursos, que totalizaram 3.346.000 alunos/ hora, eles não ultrapassaram, em média, 65 horas. ${ }^{22}$ Já os novos cursos de "qualificação profissional" de 329 horas de duração, em média, alcançaram apenas o total de 768 matrículas e 565 conclusões (253 mil alunos/hora).

Os "Treinamentos para Empresas", tradicionalmente cursos de curta duração, apresentam matrículas e conclusões crescentes desde 1995 (342.942 a 398.780 e 329.201 a 383.546, respectivamente), embora entre 1998-97, esse total tenha decrescido $4,3 \%$ e $4,0 \%$. Respondendo a críti- cas e procurando mostrar os primeiros frutos de sua reforma interna, a instituição enfatiza que o atendimento a pequenas empresas cresceu $2,3 \%$, embora o número de estabelecimentos atendidos desse porte tenha decaído 3,2\%. Os Treinamentos para Comunidade registraram crescimento contínuo. Entre os anos 1997 e 1998, as matrículas cresceram $32,2 \%$ e as conclusões, $32,7 \%$, provavelmente em virtude dos convênios com o Ministério do Trabalho (MTb) para desenvolver os cursos de (re)qualificação profissional para desempregados e/ou trabalhadores em risco de desemprego (Planfor), utilizando recursos do FAT.

No total geral, entre 1995 e 1998, o Senai-SP ampliou seu atendimento: as matrículas e conclusões se elevaram 
Ações Empresariais e Formação Profissional: Serviço Nacional...

TABELA 2

Matrículas, Conclusões, Alunos/Hora e Taxa de Evasão no Senai-SP, segundo Cursos/Treinamentos 1995-1996

\begin{tabular}{|c|c|c|c|}
\hline Cursos/Treinamentos & 1995 & 1996 & $\begin{array}{c}\text { Variação } \\
\text { 1996/95 (\%) }\end{array}$ \\
\hline \multicolumn{4}{|l|}{ Total (1) } \\
\hline Matrículas & 508.434 & 551.773 & 8,5 \\
\hline Conclusões & 462.806 & 497.863 & 7,6 \\
\hline Alunos/Hora (mil) & 61.171 & 64.766 & 5,9 \\
\hline Taxa de Evasão (\%) & 5,0 & 6,2 & - \\
\hline \multicolumn{4}{|l|}{ Aprendizagem (CAI) } \\
\hline Matrículas & 21.565 & 21.235 & $-1,5$ \\
\hline Conclusões & 7.343 & 7.856 & 7,0 \\
\hline Alunos/Hora (mil) & 25.009 & 25.276 & 1,1 \\
\hline Taxa de Evasão (\%) & 4,5 & 4,1 & - \\
\hline \multicolumn{4}{|c|}{ Ensino Técnico (HP/CQP) } \\
\hline Matrículas & 10.725 & 11.711 & 9,2 \\
\hline Conclusões & 4.457 & 5.342 & 19,9 \\
\hline Alunos/Hora (mil) & 8.883 & 9.296 & 4,6 \\
\hline Taxa de Evasão (\%) & 7,8 & 6,4 & - \\
\hline \multicolumn{4}{|c|}{ Cursos de Qualificação e } \\
\hline \multicolumn{4}{|c|}{ Requalificação (CFI/CAP/CEP) (2) } \\
\hline Matrículas & 33.613 & 29.319 & $-12,8$ \\
\hline Conclusões & 28.502 & 24.261 & $-14,9$ \\
\hline Alunos/Hora (mil) & 7.301 & 6.699 & $-8,2$ \\
\hline Taxa de Evasão (\%) & 11,4 & 12,7 & - \\
\hline \multicolumn{4}{|c|}{ Treinamento - Empresas (TI - E) (3) } \\
\hline Matrículas & 342.942 & 372.379 & 8,6 \\
\hline Conclusões & 329.201 & 352.559 & 7,1 \\
\hline Alunos/Hora (mil) & 9.880 & 12.095 & 22,4 \\
\hline Taxa de Evasão (\%) & 3,9 & 5,2 & - \\
\hline \multicolumn{4}{|c|}{ Treinamento - Comunidade ( $\mathrm{TI}-\mathrm{C})$} \\
\hline Matrículas & 98.873 & 116.647 & 18,0 \\
\hline Conclusões & 92.587 & 107.363 & 16,0 \\
\hline Alunos/Hora (mil) & 10.023 & 11.369 & 13,4 \\
\hline Taxa de Evasão (\%) & 6,4 & 8,0 & - \\
\hline
\end{tabular}

Fonte: Senai, 1997c.

(1) Inclui estágios de alunos de 20 e 3ำ graus de outras instituições de ensino $(716$ matrículas/conclusões e 76 mil alunos/hora em 1995 e 482 matrículas/conclusões e 31 mil alunos/ hora em 1996). Não inclui 3.148 certificados expedidos em exames supletivos (1.758 - disciplinas de 10 grau, 962 - disciplinas de 20 grau e 428 - profissionalizantes) - Telecurso 2000. (2) Referem-se aos cursos de formação intensiva, aperfeiçoamento e especialização.

(3) Treinamento industrial, ensino a distância, seminários e estágios para pessoal de empresas. Inclui programas realizados para atendimento a solicitações de empresas, sindicatos e outras clientelas específicas.

$27,6 \%$ e $29,5 \%$, respectivamente. No entanto, os dados indicam que cursos anteriores, de maior duração, como os de aperfeiçoamento e especialização, foram substituídos por cursos de curta duração.

Do ponto de vista das áreas ocupacionais, a área de mecânica continua a ocupar lugar expressivo na pro-
TABELA 3

Matrículas, Conclusões e Alunos/Hora no Senai-SP, segundo Áreas Ocupacionais 1996

\begin{tabular}{|c|c|c|c|c|c|c|}
\hline \multirow{2}{*}{ Áreas Ocupacionais } & \multicolumn{2}{|c|}{ Matrículas } & \multicolumn{2}{|c|}{ Conclusões } & \multicolumn{2}{|c|}{$\begin{array}{l}\text { Alunos/Hora } \\
\text { (mil) }\end{array}$} \\
\hline & №s Abs. & $\%$ & №s Abs. & $\%$ & №s Abs. & $\%$ \\
\hline Total & 551.773 & 100,0 & 497.863 & 100,0 & 64.766 & 100,0 \\
\hline Mecânica & 121.837 & 22,1 & 101.605 & 20,4 & 29.187 & 45,1 \\
\hline Eletricidade/Eletrônica & 46.214 & 8,4 & 39.358 & 7,9 & 10.017 & 15,5 \\
\hline $\begin{array}{l}\text { Construção Civil } \\
\text { Vestuário/Calçados } \\
\text { e Artefatos de }\end{array}$ & 51.317 & 9,3 & 47.079 & 9,5 & 4.710 & 7,3 \\
\hline Tecido/Têxtil & 35.480 & 6,4 & 32.228 & 6,5 & 3.942 & 6,1 \\
\hline Editorial e Gráfica & 16.315 & 3,0 & 13.747 & 2,8 & 2.193 & 3,4 \\
\hline Metalurgia/Siderurgia & 9.023 & 1,6 & 7.500 & 1,5 & 2.137 & 3,3 \\
\hline Madeira/Mobiliário & 12.373 & 2,2 & 10.883 & 2,2 & 1.861 & 2,9 \\
\hline Alimentos/Bebidas & 14.017 & 2,5 & 13.304 & 2,7 & 1.070 & 1,7 \\
\hline Química & 1.190 & 0,2 & 529 & 0,1 & 950 & 1,5 \\
\hline Plásticos/Borracha & 3.451 & 0,6 & 2.934 & 0,6 & 950 & 1,5 \\
\hline Cerâmica/Minerais & & & & & & \\
\hline Não-Metálicos & 3.658 & 0,7 & 3.011 & 0,6 & 744 & 1,1 \\
\hline Transportes & 12.213 & 2,2 & 11.527 & 2,3 & 285 & 0,4 \\
\hline Comunicações & 2.184 & 0,4 & 2.106 & 0,4 & 180 & 0,3 \\
\hline Papel e Celulose & 1.000 & 0,2 & 727 & 0,1 & 136 & 0,2 \\
\hline Desenvolvimento de & & & & & & \\
\hline Recursos Humanos & 3.992 & 0,7 & 3.906 & 0,8 & 76 & 0,1 \\
\hline Outras (1) & 5.309 & 1,0 & 4.870 & 1,0 & 509 & 0,8 \\
\hline Não-definida & & & & & & \\
\hline (mais de uma área) & 212.200 & 38,5 & 202.549 & 40,7 & 5.819 & 9,0 \\
\hline
\end{tabular}

Fonte: Senai, 1997e.

(1) Incluem joalherias, couros e administração.

dução do Senai-SP: 130.338 matrículas, que representam $20,1 \%$ do total. Entretanto, "como sinal dos tempos, que exigem o profissional eclético", o maior número de matrículas ocorreu na área denominada "não-definida". Trata-se, segundo a instituição, de "programações relacionadas a competências comuns aos profissionais de várias áreas ocupacionais: informática básica, prevenção de acidentes, princípios de cálculo técnico, qualidade, planejamento de custos, gestão da produção e outras", que apresentam 275.832 matrículas, ou seja, $42,5 \%$ do total. ${ }^{23}$

Uma última observação: embora haja crescimento no número das matrículas nos cursos das diferentes áreas mecânica, eletricidade/eletrônica, metalurgia/siderurgia , constata-se a diminuição no número de horas de formação em todos eles. O curso de mecânica, por exemplo, apresentava, em 1996, carga horária de 239 horas que, em 1998, foi reduzida para 184. 
TABELA 4

Matrículas, Conclusões, Evasões, Matrículas Residuais e Alunos/Hora no Senai-SP, segundo Modalidades Estado de São Paulo - 1998

\begin{tabular}{|c|c|c|c|c|c|}
\hline Modalidades & Matrículas & Conclusões & Evasões & Matrículas Residuais & Alunos/Hora \\
\hline TOTAL (1) & 1.331 .755 & 1.277 .625 & 38.653 & 15.477 & 73.678 .377 \\
\hline Ação Direta (2) & 649.006 & 599.427 & 34.495 & 15.084 & $64.353 .635,7$ \\
\hline Aprendizagem Industrial - Fase Escolar & 16.126 & 7.147 & 522 & 8.457 & $19.724 .664,5$ \\
\hline Qualificação Profissional & 3.806 & 3.110 & 373 & 323 & $1.013 .512,0$ \\
\hline \multicolumn{6}{|l|}{ Curso Técnico (HP) } \\
\hline Fase Escolar (2) & 2.149 & 819 & 88 & 1.242 & $2.526 .984,0$ \\
\hline Estágio & 1.971 & 420 & 9 & 1.542 & $1.947 .170,0$ \\
\hline \multicolumn{6}{|l|}{ Curso Técnico Especial (CQP - IV) } \\
\hline Fase Escolar & 2.864 & 1.157 & 288 & 1.419 & $1.886 .249,5$ \\
\hline Estágio & 1.399 & 468 & - & 931 & $1.259 .100,0$ \\
\hline \multicolumn{6}{|l|}{ Curso Técnico Modularizado - Formação } \\
\hline de Auxiliares Técnicos & 3.615 & 2.834 & 343 & 438 & $1.544 .885,0$ \\
\hline Formação de Tecnólogos & 40 & - & 4 & 36 & $15.200,0$ \\
\hline Especialização & 2.333 & 1.899 & 120 & 314 & $1.352 .686,0$ \\
\hline Aperfeiçoamento & 1.176 & 626 & 168 & 382 & $322.864,0$ \\
\hline Treinamento Industrial & 399.125 & 383.837 & 15.288 & - & $14.411 .136,0$ \\
\hline Iniciação Profissional & 161.616 & 150.068 & 11.548 & - & $14.893 .212,7$ \\
\hline Outras & 52.786 & 47.042 & 5.744 & - & \\
\hline Ação Indireta & 682.749 & 678.198 & 4.158 & 393 & $9.324 .742,0$ \\
\hline Aprendizagem Industrial - Fase Escolar & 377 & 152 & 1 & 224 & $432.650,0$ \\
\hline \multicolumn{6}{|l|}{ Curso Técnico Especial (CQP - IV) } \\
\hline Fase Escolar & 163 & 66 & 1 & 96 & $98.230,0$ \\
\hline Estágio & 78 & 5 & - & 73 & $61.460,0$ \\
\hline Treinamentos - Termos de Cooperação & 681.243 & 677.087 & 4.156 & - & $8.691 .045,0$ \\
\hline Outras & 888 & 888 & - & - & $41.357,0$ \\
\hline
\end{tabular}

Fonte: Senai, 1999.

(1) Não inclui estágios para pessoal de empresas no país e no exterior (119 matrículas, 119 conclusões e 8.916,0 alunos/hora). Não inclui, também, 30.622 certificados expedidos em exames supletivos (13.173 - disciplinas do ensino fundamental, 16.841 - disciplinas do ensino médio e 608 - profissionalizantes) - Telecurso 2000.

(2) No caso do regime semestral, inclui até o $6^{0}$ semestre da fase escolar. 0 70 semestre acha-se somado com o estágio.

A nova estratégia pedagógica sugere, de imediato, a existência de alguns pontos críticos.

Educação Geral x Educação Profissional/Técnica - De acordo com seu novo modelo de formação profissional, o Senai propõe diminuir e até desativar os cursos que realizam ensino com equivalência, isto é, aquele tipo de aprendizagem em que o aluno realiza, em tempo integral, as quatro últimas séries do ensino fundamental mais a parte profissionalizante de forma conjunta. No caso do ensino técnico de nível médio, conforme o disposto pela nova legislação (inspirada no próprio modelo Senai), generalizam-se os cursos modularizados após o ensino regular médio, instituindo a separação entre a formação geral e técnica. Três problemas se colocam, então:

- o novo modelo reforça a continuidade da antinomia formação geral/formação profissional, a existência de redes diversificadas - educação geral e profissionalizante -, além de desconsiderar a educação básica como parte essencial da educação técnica, "o que enfraquece a idéiaforça de superação da crise educacional brasileira" (Salm e Fogaça, 1995);

- de acordo com o Senai, os novos conteúdos curriculares têm por objetivo formar não só o aluno polivalente capaz de exercer várias funções no processo produtivo, mas que possua, também, características politécnicas, ou seja, com formação em mais de uma profissão. A vinculação entre eletrônica e eletricidade constitui uma das iniciativas citadas para a diversificação profissional. Entretanto, como considera justamente um estudo do Dieese (1997), essas ações estão longe de reverter a fragmentação das profissões, típica do paradigma taylorista/fordista. A adaptação das grades curriculares às mudanças no conteúdo do trabalho, em que as profissões podem desapare- 
Ações Empresariais e Formação Profissional: Serviço Nacional...

TABELA 5

Matrículas, Conclusões, Alunos/Hora e Taxa de Evasão no Senai, segundo Cursos/Treinamentos Estado de São Paulo - 1997-98

\begin{tabular}{|c|c|c|c|}
\hline Cursos/Treinamento & 1997 & $\begin{array}{c}1998 \\
(1)\end{array}$ & $\begin{array}{l}\text { Variação } \\
1998 / 97(\%)\end{array}$ \\
\hline \multicolumn{4}{|l|}{ Total (2) } \\
\hline Matrículas & 591.657 & 649.125 & 9,7 \\
\hline Conclusões & 543.538 & 599.546 & 10,3 \\
\hline Alunos/Hora (mil) & 64.247 & 64.363 & 0,2 \\
\hline Taxa de Evasão (\%) & 5,1 & 5,3 & 0,2 \\
\hline \multicolumn{4}{|c|}{ Aprendizagem Industrial } \\
\hline Matrículas & 19.500 & 16.126 & $-17,3$ \\
\hline Conclusões & 7.523 & 7.147 & $-5,0$ \\
\hline Alunos/Hora (mil) & 23.704 & 19.725 & $-16,8$ \\
\hline Taxa de Evasão (\%) & 4,1 & 3,2 & - \\
\hline \multicolumn{4}{|l|}{ Ensino Técnico } \\
\hline Matrículas & 12.298 & 11.998 & $-2,4$ \\
\hline Conclusões & 5.932 & 5.698 & $-3,9$ \\
\hline Alunos/Hora (mil) & 9.566 & 9.164 & $-4,2$ \\
\hline Taxa de Evasão (\%) & 6,8 & 6,1 & - \\
\hline \multicolumn{4}{|l|}{ Ensino Superior } \\
\hline Matrículas & 0 & 40 & - \\
\hline Conclusões & 0 & 0 & - \\
\hline Alunos/Hora (mil) & 0 & 15 & - \\
\hline Taxa de Evasão (\%) & 0 & 10,0 & - \\
\hline \multicolumn{4}{|c|}{$\begin{array}{l}\text { Estágios de Alunos de Outras } \\
\text { Instituições de Ensino }\end{array}$} \\
\hline Matrículas & 619 & 607 & $-1,9$ \\
\hline Conclusões & 619 & 607 & $-1,9$ \\
\hline Alunos/Hora (mil) & 89 & 110 & 23,8 \\
\hline Taxa de Evasão (\%) & 0,0 & 0,0 & - \\
\hline \multicolumn{4}{|c|}{$\begin{array}{l}\text { Formação Intensiva/Aperfeiçoamento/ } \\
\text { Especialização }\end{array}$} \\
\hline Matrículas & 19.958 & 6.547 & $-67,2$ \\
\hline Conclusões & 16.596 & 5.070 & $-69,5$ \\
\hline Alunos/Hora (mil) & 5.009 & 2.437 & $-51,4$ \\
\hline Taxa de Evasão (\%) & 11,4 & 9,7 & - \\
\hline \multicolumn{4}{|l|}{ Programas Flexíveis } \\
\hline Matrículas & 0 & 52.179 & - \\
\hline Conclusões & 0 & 46.435 & - \\
\hline Alunos/Hora (mil) & 0 & 3.346 & - \\
\hline Taxa de Evasão (\%) & 0 & 11,0 & - \\
\hline \multicolumn{4}{|c|}{ Qualificação Profissional } \\
\hline Matrículas & 0 & 768 & - \\
\hline Conclusões & 0 & 565 & - \\
\hline Alunos/Hora (mil) & 0 & 253 & - \\
\hline Taxa de Evasão (\%) & 0 & 3,1 & - \\
\hline \multicolumn{4}{|c|}{ Treinamentos para Empresas } \\
\hline Matrículas & 416.721 & 398.780 & $-4,3$ \\
\hline Conclusões & 399.443 & 383.546 & $-4,0$ \\
\hline Alunos/Hora (mil) & 14.422 & 14.376 & $-0,3$ \\
\hline Taxa de Evasão (\%) & 4,1 & 3,8 & - \\
\hline \multicolumn{4}{|c|}{ Treinamentos para Comunidade } \\
\hline Matrículas & 122.561 & 162.080 & 32,2 \\
\hline Conclusões & 113.425 & 150.478 & 32,7 \\
\hline Alunos/Hora (mil) & 11.457 & 14.937 & 30,4 \\
\hline Taxa de Evasão (\%) & 7,5 & 7,2 & - \\
\hline
\end{tabular}

Fonte: Senai, 1997e.

(1) Dados referentes, basicamente, ao 2o semestre de 1998.

(2) Não inclui certificados expedidos em exames supletivos (13.173 - disciplinas de ensino fundamental, 16.841 - disciplinas de ensino médio e 608 - profissionalizantes). Telecurso 2000.

(3) Treinamento industrial, ensino a distância, seminários e estágios para pessoal de empresas.
TABELA 6

Conclusões nos Programas de Treinamento Industrial - Empresas no Senai e Número de Estabelecimentos Atendidos, segundo Porte Estado de São Paulo - 1997-98

\begin{tabular}{|c|c|c|c|c|c|}
\hline \multirow{2}{*}{ Porte dos Estabelecimentos } & \multicolumn{2}{|c|}{1997} & \multicolumn{2}{|c|}{1998} & \multirow{2}{*}{$\begin{array}{c}\text { Variaçãc } \\
1998 / 97 \\
(\%)\end{array}$} \\
\hline & №s Abs. & $\%$ & №s Abs. & $\%$ & \\
\hline Conclusões (1) & 283.650 & 100,0 & 267.853 & 100,0 & $-5,6$ \\
\hline Pequeno (Até 99 Empregados) & 96.922 & 34,2 & 99.131 & 37,0 & 2,3 \\
\hline Médio (100 a 499 Empregados) & 73.031 & 25,7 & 66.062 & 24,7 & $-9,5$ \\
\hline Grande (500 ou Mais) & 113.697 & 40,1 & 102.660 & 38,3 & $-9,7$ \\
\hline
\end{tabular}

Número de Estabelecimentos

$\begin{array}{lrrrrr}\text { Atendidos } & \mathbf{5 . 9 8 0} & \mathbf{1 0 0 , 0} & \mathbf{5 . 5 2 6} & \mathbf{1 0 0 , 0} & \mathbf{- 7 , 6} \\ \text { Pequeno (Até 99 Empregados) } & 3.119 & 52,2 & 3.019 & 54,6 & -3,2 \\ \text { Médio (100 a 499 Empregados) } & 1.931 & 32,3 & 1.687 & 30,5 & -12,6 \\ \text { Grande (500 ou Mais) } & 930 & 15,6 & 820 & 14,8 & -11,8\end{array}$

Fonte: Senai, 1997e.

(1) Excluem treinandos não-indicados por estabelecimentos/empresas.

TABELA 7

Matrículas, Conclusões e Alunos/Hora no Senai, segundo Áreas Ocupacionais Estado de São Paulo - 1998

\begin{tabular}{|c|c|c|c|c|c|c|}
\hline \multirow[t]{2}{*}{ Áreas Ocupacionais } & \multicolumn{2}{|c|}{ Matrículas } & \multicolumn{2}{|c|}{ Conclusões } & \multicolumn{2}{|c|}{$\begin{array}{l}\text { Alunos/Hora } \\
\text { (Mil) }\end{array}$} \\
\hline & №s Abs. & $\%$ & №s Abs. & $\%$ & №s Abs. & $\%$ \\
\hline Total & 649.125 & 100,0 & 599.546 & 100,0 & 64.363 & 100,0 \\
\hline Mecânica & 130.388 & 20,1 & 114.743 & 19,1 & 24.052 & 37,4 \\
\hline Eletricidade/Eletrônica & 59.450 & 9,2 & 52.484 & 8,8 & 9.612 & 14,9 \\
\hline $\begin{array}{l}\text { Construção Civil } \\
\text { Vestuário/Calçados e }\end{array}$ & 55.752 & 8,6 & 51.656 & 8,6 & 4.935 & 7,7 \\
\hline Artefatos de Tecido/Têxtil & 33.246 & 5,1 & 30.413 & 5,1 & 3.883 & 6,0 \\
\hline Editorial e Gráfica & 14.964 & 2,3 & 13.371 & 2,2 & 2.212 & 3,4 \\
\hline Metalurgia/Siderurgia & 9.206 & 1,4 & 7.945 & 1,3 & 1.611 & 2,5 \\
\hline Madeira/Mobiliário & 11.081 & 1,7 & 9.885 & 1,6 & 1.726 & 2,7 \\
\hline Alimentos/Bebidas & 15.594 & 2,4 & 14.720 & 2,5 & 1.464 & 2,3 \\
\hline Plásticos/Borracha & 3.309 & 0,5 & 2.827 & 0,5 & 898 & 1,4 \\
\hline Química & 1.233 & 0,2 & 627 & 0,1 & 902 & 1,4 \\
\hline \multicolumn{7}{|l|}{ Cerâmica/Minerais } \\
\hline Não-Metálicos & 1.462 & 0,2 & 1.138 & 0,2 & 481 & 0,7 \\
\hline Transportes & 15.593 & 2,4 & 15.319 & 2,6 & 372 & 0,6 \\
\hline Comunicações & 2.281 & 0,4 & 2.245 & 0,4 & 204 & 0,3 \\
\hline Papel e Celulose & 365 & 0,1 & 294 & 0,0 & 90 & 0,1 \\
\hline \multicolumn{7}{|l|}{ Desenvolvimento de } \\
\hline Recursos Humanos & 2.727 & 0,4 & 2.665 & 0,4 & 80 & 0,1 \\
\hline Não-definida & & & & & & \\
\hline (mais de uma área) & 275.832 & 42,5 & 264.393 & 44,1 & 10.663 & 16,6 \\
\hline Outras (1) & 16.642 & 2,6 & 14.821 & 2,5 & 1.178 & 1,8 \\
\hline
\end{tabular}

Fonte: Senai, 1997e.

(1) Incluem joalherias, couros e administração. 
cer e se transformar, tem um pressuposto: o trabalhador terá que se reciclar permanentemente. Em outras palavras: o novo modelo incorre no risco da excessiva fragmentação dos cursos modulares - da formação básica, qualificação e, mesmo, os técnicos/pós-médio. A montagem dos itinerários ocupacionais, ao procurar atender as demandas pontuais das empresas, pode causar formações adaptativas/instrumentais às mudanças, perdendo de vista os objetivos declarados do aprendizado teórico mais amplo e integrado dos fundamentos científicos e tecnológicos indispensáveis à formação do trabalhador polivalente e flexível;

- ao elevar o grau de exigência da escolaridade para o ingresso nos cursos, a instituição está excluindo de sua clientela parcelas substantivas da população, dada a baixa escolaridade média da população brasileira (Dieese, 1997). Mesmo que as matrículas nos "Treinamentos para a Comunidade" tenham aumentado, esses cursos inscrevem-se, em sua maioria, no Planfor - Plano Nacional de Formação/MTb, o que significa que seu formato, tal como está ali definido, exclui a interação com a educação básica fundamental, referendando a exclusão daqueles milhares de trabalhadores que não tiveram a possibilidade de se escolarizar na idade própria.

A Oferta do Senai é Dirigida a Trabalhadores Empregados - Como se viu, é opção política da instituição não atender o desempregado. No caso dos cursos de reconversão ou requalificação profissional, as pesquisas realizadas pela instituição indicam que eles representaram, no período 1995/96, apenas $8 \%$ das matrículas do Senai, cuja principal via de reconversão foi o reemprego no setor formal, e o maior demandante é o governo que financia os cursos a serem implementados (Senai, 1997b). Além disso, os estudos também mostram que esses cursos são de curta duração, além de não possuírem um perfil específico próprio.

Senai Dirige-se ao Mercado Formal de Trabalho e Atende Fundamentalmente as Grandes Empresas - Isso significa que grande parcela da população empregada nas pequenas e médias empresas, e os trabalhadores autônomos estão excluídos dos cursos oferecidos pela instituição. De acordo com sua nova estratégia de funcionamento, o Senai dispõe-se a ampliar seu atendimento às pequenas e médias empresas, por meio da realização de cursos e consultorias técnicas. No entanto, para a autosustentação, esses serviços deverão ser pagos, assim como os cursos destinados a trabalhadores não-indicados por empresas, o que constitui outra forma de seletividade econômica. Pode-se indagar, também, se a pretensão de cobrança de cursos não consiste em abuso, eticamente contestável, uma vez que essa instituição, embora de gestão privada, vive de recursos públicos.

A Clientela do Senai é Esmagadoramente do Sexo Masculino - Tal informação não chega a surpreender porque é na indústria, entre os grandes setores da economia, que as mulheres estão em menor número. Segundo pesquisa do Dieese, das 29.820.663 mulheres que estavam no mercado de trabalho no Brasil, em 1997, 8 milhões trabalhavam na prestação de serviços, 6 milhões, na agricultura, 4,5 milhões, nas atividades sociais, 3,5 milhões, no comércio e apenas 2,5 milhões trabalhavam na indústria (Dieese, 1997). A participação feminina é numericamente insignificante no setor metalmecânico, em que o domínio da tecnologia e das máquinas é considerado habilidade masculina. Portanto, a pequena presença de mulheres nos cursos do Senai manifestam a situação das indústrias. De qualquer maneira, os dados indicam que a qualificação profissional está sendo direcionada de forma gritante para um desenvolvimento desigual entre gêneros no mercado de trabalho (Dieese, 1997).

Em síntese, concordando com as projeções realizadas pelo próprio Sistema Senai, pode-se afirmar que, diante das demandas intensas e diversificadas de formação profissional, institucionaliza-se hoje o dualismo na organização de sua oferta: de um lado, a formação "de ponta" para segmentos industriais competitivos, realizada pelo Senai e pelas próprias empresas (e suas respectivas parcerias), de outro, a formação compensatória para os demais, financiada pelo Estado, com os recursos do Fundo de Amparo do Trabalhador (FAT). É importante enfatizar que mesmo as políticas públicas compensatórias de formação profissional, uma vez que desconsideram a possibilidade da recuperação da escolaridade da população brasileira, de propiciar o exercício do direito à educação a milhares de pessoas que não tiveram acesso à escolarização na idade própria, não se propõem a promover a inclusão, mas a justificar a exclusão desses segmentos sociais (Moraes, 1998).

\section{NOTAS}

E-mail da autora: moraescs@usp.br

O artigo é uma síntese do texto elaborado no âmbito do projeto "Diagnóstico da Formação Profissional - Ramo Metalúrgico” (1999), desenvolvido sob a res- 
ponsabilidade da Rede Unitrabalho, como parte do Programa Integrar Nacional de Formação e Requalificação Profissional, da Confederação Nacional dos Metalúrgicos - CNM/CUT.

1. O Senai integra o chamado Sistema "S", um conjunto de instituições destinadas a prestar serviços a empresas dos diferentes setores da economia. Além do Senai, constituem o Sistema "S": Serviço Social da Indústria - Sesi, Serviço Nacional de Aprendizagem Comercial (Senac), Serviço Social do Comércio (Sesc), Serviço Nacional de Aprendizagem Rural (Senar), Serviço Nacional de Aprendizagem do Transporte (Senat), Serviço Social do Transporte (Sest), Serviço Brasileiro de Apoio às Micro e Pequenas Empresas (Sebrae)

2. O Decreto no 100.009 de 16/07/42 aprovou o Regimento Interno da nossa instituição. De acordo com seu artigo 2o, o Senai deveria funcionar em íntima colaboração e articulação com os estabelecimentos industriais, para estabelecer um sistema nacional de aprendizagem; em seu artigo 27, constava que "as escolas e cursos de aprendizagem seriam instituídos e entrariam em funcionamento gradualmente, de acordo com as necessidades e conveniências da economia nacional" (O Senai de São Paulo, 1994).

3. O total de recursos disponíveis ao Sistema "S"-Senai, Senac, Senar e Senat, incluindo as entidades "sociais", foi, em 1998, de 4,350 bilhões de reais, quase 12 vezes os recursos destinados ao Plano Nacional de Educação Profissional (Planfor), os quais alcançaram nesse mesmo ano o total de 414 milhões de reais (previstos), sendo efetivamente gastos $\mathrm{R} \$ 397.000 .753,00$ (Castionni, 1999). Os recursos destinados ao Senai atingem, aproximadamente, 1,9 bilhão de reais/ano.

4. As informações sobre a estrutura e organização do Senai, assim como sobre as modalidades de ensino ofertadas, encontram-se em Senai (1996, 1997a, 1997c e 1997f).

5. Diante do panorama de modernização da economia e da indústria no país, há considerável esforço institucional de atualização tecnológica e no campo da metodologia de formação: desenvolvimento de Centros Nacionais de Tecnologia, nas diferentes regiões do país, incentivados por um sistema de avaliação de qualidade dos serviços prestados em educação, assistência técnica e assistência tecnológica, que os classifica em três níveis: bronze, prata e ouro. O Senai contava em 1997 com 40 centros candidatos ao título de Cenatec, 27 dos quais já se certificaram na categoria bronze. Esses centros desenvolveram competência específica em 23 áreas tecnológicas, encontrando-se implantados em dez estados da federação, nas regiões Sul, Sudeste e Nordeste do país; nove pertencem ao Senai-SP, nas áreas automobilística, eletrônica, mecânica, mecânica de precisão e mecatrônica. A região Nordeste caracteriza-se pela grande quantidade de unidades móveis $(33,76 \%)$, veículo de atuação significativa no interior do país (Senai, 1996; Senai, 1997a)

6. Entre as medidas que visam transformar o Senai em instituição "compacta, enxuta, menor e mais eficiente" está o corte de $8 \%$ de seus funcionários, principalmente do pessoal administrativo e gerencial (16\%). De acordo com os dados fornecidos pela instituição, entre 1992 e 1996, o percentual de professores demitidos foi maior que o dos técnicos e as demissões ocorreram, majoritariamente, nas regiões Nordeste e Centro-Oeste.

7. Ver Bezerra (1997). Fernando Bezerra era, na época, Presidente do CNI e do Conselho Nacional do Senai.

8. De acordo com Cunha (1997), na assessoria ao MEC, no governo empossado em janeiro de 1995, Moura Castro atuou com João Batista Oliveira, que também havia integrado os quadros técnicos do Bird, do BID e da OIT e, como ele, com formação doutoral norte-americana. Oliveira ocupou a secretaria geral do MEC por menos de um ano, após o que vem se dedicando à consultoria a governos estaduais e administrações municipais, assim como a organismos empresariais em questões de educação. Ainda, segundo o autor, Castro e Oliveira formaram uma parceria que tem exercido significativa influência nas políticas educacionais no nível federal e no estadual.

9. Moura Castro desenvolve bem a questão na perspectiva do BID: "A formação profissional moderna requer muitas pontes entre a escola e a empresa. Tradicionalmente, produzia-se uma transição abrupta entre a capacitação e o mercado de trabalho. Ainda quando ocorriam estágios, eram no geral um agregado formal e não verdadeiros laços entre a instituição de ensino e o mundo do trabalho. Diante da crescente complexidade das tecnologias, nem as escolas podem desenvolver plenamente o ambiente necessário para aprender, nem as empresas oferecer a gama de conhecimentos teóricos que as tecnologias demandam. Portanto, é preciso criar uma diversidade de pontes entre a formação e o trabalho. Os estágios são planificados e supervisionados de forma mais rigorosa por ambos os extremos. Os docentes passam períodos nas empresas e fábricas e os engenheiros nas escolas. Realizam-se projetos conjuntos entre escolas e fábricas, desenvolvem-se projetos de $\mathrm{P} \& \mathrm{D}$ nos quais intervêm estudantes e funcionários das empresas" (Moura Castro, 1999).
10. Segundo Oliveira (1995) "o Brasil possui poucas - e muitas delas - boas escolas técnicas. Grande parte da reputação das escolas técnicas, no entanto, não se deve à sua contribuição para a eficiência das empresas, mas para o sucesso dos alunos no exame vestibular. O sistema é caro - no federal são quase 600 milhões de reais para 150 mil alunos, ou seja, 4 mil dólares por aluno/ano. Compare-se esse valor com o custo médio de 250 reais por aluno de curso secundário no Estado de São Paulo. É muito dinheiro para preparar candidatos a bacharéis!”. Observa-se que o argumento é o mesmo, repetido à exaustão pelo governo e seus assessores - ventríloquos dos organismos multilaterais: o ensino técnico, apesar da boa qualidade, é elitizado e onera o governo federal; as parcerias viriam amenizar os seus gastos. A relação custo-benefício ignora os aspectos qualitativos, ou seja, a condição calamitosa do ensino médio estadual, as péssimas condições de trabalho vigentes nessas escolas, motivo principal de seus custos menores.

11. É o que Cunha (1997) denominou de "senaizição das escolas técnicas federais", que, para ele, é "o complemento da autoprivatização do Senai", isto é, dos processos em curso na instituição na busca estratégica da auto-sustentação. Sobre a análise das políticas públicas de educação e formação profissional, ver Moraes e Ferretti (1999), especialmente parte I, cap. 2.

12. A partir da implantação do Planejamento Estratégico, instrumento de gerenciamento de sua modernização, o Senai tem direcionado a atuação na busca da integração entre todas as diretorias regionais e a direção nacional, através do desenvolvimento de uma série de projetos de abrangência nacional, multirregional e regional. Do acordo com o Senai, esses projetos, "de alto valor estratégico", estão "orientados para a melhoria da eficiência interna institucional e para o apoio de áreas ou setores prioritários para a economia dessas regiões" (Senai/1996; Senai, 1997a). Para maior detalhamento das ações de mudança implementadas pelo Senai, consultar Moraes e Ferretti (1999).

13. Na Alemanha, em meados da década de 70 , já se avaliava que o perfil do egresso do sistema de formação profissional não estava atendendo às necessidades das empresas industriais. Isto é, desejava-se que os trabalhadores apresentassem, além da capacitação técnica, os atributos pessoais para permitir sua pronta adaptação às mudanças. Para desenvolver tais atributos, várias empresas, que são responsáveis, nesse país, por grande parte da formação profissional, iniciaram a aplicação experimental de modelos. A Siemens, baseada nos resultados dessas aplicações em algumas empresas (Daimler, Bens, Ford, Hoesch, ZKF), concebeu o Modelo Petra (formação orientada para o projeto e a transferência) que, após aprovação pelo Ministério de Educação e Ciência da Alemanha, foi implantado e validado em seu complexo industrial a partir de fevereiro de 1985 Na sigla Petra, duas palavras são fundamentais: projeto e transferência. Assim, a promoção nos alunos dos atributos pessoais realiza-se durante o desenvolvimento de um projeto técnico. Nesse contexto, projeto é entendido como uma tarefa, com graus variados de complexidade e de difícil solução, e transferência significa a aplicação de conhecimentos, habilidades e atitudes em situações novas ou modificadas (Franceschini, Gonçalves e Cruz, 1996).

14. A Piam é uma das linhas de estudo sobre o mercado de trabalho que o SenaiSP realiza regularmente, a cada dois anos, desde 1990, em todo o Estado.

15. Foram estudadas as empresas contribuintes do Senai, em cada área de abrangência das escolas, atingindo cerca de 1.083 unidades produtivas e $414 \mathrm{mil} \mathrm{em-}$ pregados em 129 municípios. Foram, também, analisados 275 estabelecimentos não-contribuintes. Das unidades pesquisadas, $31 \%$ são de pequeno porte, $51 \%$, de médio e $18 \%$, de grande porte. Quanto ao número de empregados, verifica-se que as plantas de grande porte reúnem mais de $60 \%$ da mão-de-obra, enquanto as médias absorvem aproximados $32 \%$ e as de pequeno porte, somente $4 \%$. (Senai, 1997b).

16. Entrevista com diretores dos Departamentos do Senai, 26/11/1997.

17. Em pesquisa recente realizada pelo Senai-SP sobre as qualidades de um "bom profissional", os participantes - pessoal de liderança, chefia e supervisão na área de produção das empresas - "julgaram 'que ser capaz de, além de executar seu trabalho, também programá-lo' é mais importante do que 'ser curinga' (ser multitarefa)" (Assis, 1994).

18. Para informações detalhadas a respeito dos resultados das pesquisas realizadas pelo Senai, em especial os Senais regionais SP e RJ, e sua incidência na construção dos novos modelos de formação, consultar Moraes e Ferretti (1999).

19. O novo modelo substitui as modalidades de formação ofertadas até então: aprendizagem, qualificação, habilitação profissional, formação de tecnólogos e as chamadas ações de suprimento.

20. Segundo Rainbird, as teorias subjacentes à definição de competência têm sido objeto de inúmeras críticas por pedagogos e sociólogos da educação. Eles têm frisado "a pequena importância atribuída aos processos e aos contextos de 
aprendizagem cognitiva, de modo a possibilitar que o saber venha a ser transmitido e utilizado de maneira criativa em diferentes situações". Alguns enfatizam ser o modelo "fundado em teorias fluidas e pouco sofisticadas", o que tem conseqüências: "os pressupostos funcionalistas e behavioristas produzem um modelo unidimensional e normativo, no qual não há espaço para o indivíduo nem para uma contribuição pessoal do estagiário. O estagiário deve permanecer passivo e reproduzir os gestos ensinados no momento desejado" (Marshall apud Rainbird, 1995). A "inadequação da noção de competência à complexidade das atividades e das interações humanas" também é sublinhada: a noção de competência reflete um individualismo e um desconhecimento inquietante da importância do contexto social. De maneira geral, consideramos que a competência reflete um modo de raciocínio mecânico orientado para a técnica, que é normalmente não-adaptada às ações humanas ou à satisfação dos seres humanos. Quanto mais a ação é 'humana', no sentido de não ser mecânica, mas criativa ou sensível, menos a competência consiste em preparação adequada à ação" (Ashworth e Saxton apud Rainbird, 1995).

21. O seguro-desemprego, além da baixa remuneração, tem vigência curta e atende apenas os empregados com relações formais de trabalho (aproximadamente $40 \%$ da PEA).

22. Esse dado é obtido dividindo-se, a cada ano, o número de alunos/hora pelo número de matriculados.

23. Foram reestruturados currículos em 21 habilitações profissionais e, entre elas, as que nos interessam: eletrônica, gestão de processos industriais, instrumentação e controle de processos, informática industrial/mecatrônica, mecânica, mecânica de precisão, metalurgia. Segundo a instituição, durante 1998, mais de 16 escolas passaram a oferecer cursos e programações de acordo com a proposta do novo modelo de educação profissional (Senai, 1999).

\section{REFERÊNCIAS BIBLIOGRÁFICAS}

ASSIS, M. O Senai avaliado por seus usuários. São Paulo, Senai-SP/DOP/DPPA, 1994.

BEZERRA, F. "Palavra do Presidente". In: Senai. Relatório Senai SP - 1996. São Paulo, Fiesp/Ciesp/Sesi/Senai, 1997.

BRIGIDO, R.V. (Consultor do projeto). Documento base: Projeto de Criação de um Sistema Nacional de Certificação Ocupacional. Projeto Cert/DIV MTb/Sefor/OIT, novembro 1998, mimeo.

CASTIONI, R. Avaliação de políticas públicas: modelos e usos de avaliação de impacto em programas de formação profissional. São Paulo, 1999, mimeo.

CUNHA, L.A. Ensino médio e ensino profissional: da fusão à exclusão. Rio de Janeiro, 1997, mimeo.

DEFUNE, D. "Revisão de categorias ocupacionais". Referenciais do mercado de trabalho - Projeto Reformulação do Modelo de Formação Profissional. São Paulo, DPP/DPPA/DE - Senai-SP, junho 1997.

DELUIZ, N. "A globalização econômica e os desafios à formação profissional". Boletim Técnico do Senac, v.22, n.2, maio-ago. 1996

DIEESE. "Qualificação, formação e emprego em Santa Catarina." Estudo Regional Dieese, n.2, dezembro, 1997.

."Eqüidade de gênero nas negociações coletivas: cláusulas relativas ao trabalho da mulher no Brasil." Estudo Regional Dieese, n.2, 1997.

FERRETTI, C. Comentários sobre o documento Diretrizes Curriculares para o Ensino Profissional de Nivel Técnico MEC/CNE. São Paulo, 1999, mimeo.

FRANCESCHINI, H., GONÇALVES, M. e CRUZ, S., "O Modelo Petra de formação profissional”. In: MARKET, W. (org.). Trabalho, qualificação $e$ politecnia. Campinas, Papirus Editora, 1996.

HIRATA, H . "Da polarização das qualificações ao modelo da competência". In: FERRETTI, C.; ZIBAS, D.; MADEIRA, F. e FRANCO, M.L. Tecnologias, trabalho e educação. Petrópolis, Vozes, 1994.

JOUBIER, J.M. "La flexibilité des systèmes de formation". In: Se former tout ao long de la vie. Entretiens Condorcet. VI èmes rencontres de la Formation Professionnelle/ 30 septembre et ler. octobre 1996, Paris, Le Monde Éditions/ Ministère du Travail et des Affaires Sociales, 1997.
MERLE, V. "La construction progressive des compétences". In: Se former tout ao long de la vie. Entretiens Condorcet. VI èmes rencontres de la Formation Professionnelle/30 septembre et 1er. octobre 1996, Paris, Le Monde Éditions/ Ministère du Travail et des Affaires Sociales, 1997.

MORAES, C.S.V. "A reforma do ensino médio e a educação profissional". In Trabalho e Educação. Revista do NETE (Núcleo de Estudos sobre Trabalho e Educação), FaE/UFMG, n. 3, jan.-jul., 1998.

MORAES, C.S.V. et alii. Documento subsídio da CUT nacional à discussão sobre certificação profissional por competências na Comissão Temática II "Em prego, Migrações, Qualificação e Formação Profissional” no Mercosul. São Paulo, 1998, mimeo.

MORAES, C.S.V. e FERRETTI, C. (coord.). Diagnóstico da formação profissional. Ramo metalúrgico. São Paulo, CNM-CUT/Rede Unitrabalho, 1999.

MOURA CASTRO, C. "Estrategias de Capacitación para el BID”. Documentos de Referencia/2. Unidad de Educación, Departamento de Desarrollo Sustentable, Banco Interamericano de Desarrollo, XXXIV Reunión de la Comisión Técnica, Montevideo, 8-10 abril 1999.

OLIVEIRA, J.B.A. "Novos rumos da formação profissional”. Seminário Internacional Fiemg: Novos Rumos da Formação Profissional, 27 out. 1995, mimeo.

PAOLI, M.C. "Apresentação e introdução". In: OLIVEIRA, F. e PAOLI, M.C. (orgs). Os sentidos da democracia. Políticas do dissenso e hegemonia global. Petrópolis, Vozes, Nedic, 1999.

RAINBIRD, H. "La construction sociale de la qualification". In: JOBERT, A., MARRY, C., TANGUY, L. Éducation et travail en Grande-Bretagne, Allemagne et Italie. Paris, Armand Colin Éditeur, 1995.

SALM, C. e FOGAÇA, A. Questões críticas da educação brasileira. Consolidação de propostas e subsídios para ações nas áreas da tecnologia e da qualidade. MCT/Programa de Apoio à Capacitação Tecnológica da Indústria; MICT/Programa Brasileiro de Qualidade e Produtividade, 1995.

SENAI. Certificação ocupacional. Ação estratégica nacional - 6.Termo de referência. São Paulo, DN - Senai, set. 1995.

Premissas e diretrizes operacionais da educação para o trabalho. Reestruturação do(s) Modelo(s) de Formação Profissional do Senai. Ação Estratégica Nacional 01. São Paulo, CNI/Senai/Ciet, 1996.

Problemas e soluções. Resultados da XXXIX Reunião Nacional de Diretores do Senai. São Paulo, CNI/ Senai/Ciet, 1997a.

Relatório Senai SP - 1996. São Paulo, Fiesp/Ciesp/Sesi, 1997b.

Referenciais do Mercado de Trabalho - Projeto Reformulação do Modelo de Formação Profissional. São Paulo, DPP/DPPA/DE - Senai, jun. $1997 \mathrm{c}$

Revisão do Modelo de Educação Profissional do Senai-SP. São Paulo, Diretoria Regional/ Diretoria de Educação, maio 1997d (Versão preliminar).

Focalização do ambiente externo estadual. Avaliação institucional. DOP/DPPA - DR/SP, agosto 1997e.

Ações e compromissos. Relatório do Sistema Senai - 1996. São Paulo, CNI/Senai, 1997f.

. Ayer, hoy y manãna. Educación para el trabajo y la ciudadanía. CNI/ Senai, $1997 \mathrm{~g}$.

Levantamento das atividades de reconversão profissional do Senai. São Paulo, Ciet/CNI/Senai-DN, 1997h (Pesquisa).

Relatório Senai SP - 1998. São Paulo, Departamento Nacional de Aprendizagem Nacional e Departamento Regional de São Paulo, 1999.

TANGUY, L. (coord.) L'introuvable relation formation/emploi. Un état de recherches en France. Paris, La Documentation Française, 1986.

. "L'formation, une activité sociale en voie de définition?". In: COSTER, M. e PICHAUT, F. (orgs.) Traité de Sociologie du Travail. Bruxelles, De Boeck Université, 1994.

TANGUY, L. e RAINBIRD, H. "Institutions et marché au fondement des relations entre l'éducation et le travail en Grande-Bretagne". In: JOBERT, A.; MARRY, C. e TANGUY, L. Éducation et travail en Grande-Bretagne, Allemagne et Italie, Paris, Armand Colin Éditeur, 1995. 